Review

\title{
Editorial of Special Issue Ruthenium Complex: The Expanding Chemistry of the Ruthenium Complexes
}

\author{
Ileana Dragutan ${ }^{1, \dagger, *}$, Valerian Dragutan ${ }^{1, \dagger, *}$ and Albert Demonceau ${ }^{2, \dagger, *}$ \\ 1 Romanian Academy, Institute of Organic Chemistry "C.D. Nenitescu”, Bucharest 060023, Romania \\ 2 Department of Chemistry, University of Liège, Sart-Tilman (B.6a), Liège 4000, Belgium \\ $\dagger$ These authors contributed equally to this work. \\ * Authors to whom correspondence should be addressed; E-Mails: idragutan@yahoo.com (I.D.); \\ vdragutan@yahoo.com (V.D.); A.Demonceau@ulg.ac.be (A.D.); Tel.: +40-21-316-7900 (I.D. \& V.D.); \\ +32-4-366-3495 (A.D.).
}

Academic Editor: J. Derek Woollins

Received: 6 August 2015 / Accepted: 11 September 2015 / Published: 18 September 2015

\begin{abstract}
Recent trends in $\mathrm{Ru}$ complex chemistry are surveyed with emphasis on the development of anticancer drugs and applications in catalysis, polymers, materials science and nanotechnology.
\end{abstract}

Keywords: ruthenium complexes; anticancer agents; catalysis; nanomaterials

\section{Introduction}

Over the last couple of years, the field of coordination and organometallic chemistry of ruthenium has grown and evolved at unprecedented rates. Recent publications largely highlight key advances on Ru-based complexes and on their chemically addressable applications in challenging areas like biology, medicine, catalysis, nanoscience, redox and photoactive materials, etc. [1-5]. This explosive expansion is mainly due to the unique ability of the ruthenium core to permit multiple oxidation states, hence versatile electron-transfer pathways.

Both $\mathrm{Ru}(\mathrm{II})$ and $\mathrm{Ru}(\mathrm{III})$ oxidation states accommodate six-coordinated octahedral configurations in which the additional axial ligands help fine-tune the steric and electronic properties of the complexes. Of consequence are also the relative weakness of certain metal-ligand bonds as well as the thermodynamic and kinetic stability of $\mathrm{Ru}(\mathrm{III})$-complexes $v s$. $\mathrm{Ru}(\mathrm{II})$-complexes since ligand exchange 
kinetics are immediately affected [6]. Proper variations of ancillary ligands, allowing modulation of redox properties and ligand interactions, have resulted in a large platform of Ru complexes endowed with achiral or chiral configurations [7-14]. While older research takes new directions, cutting-edge applications have emerged in the already mentioned fields, yet also in materials science, petrochemistry, and oleochemistry. Further valorization of $\mathrm{Ru}$ complexes in photochemistry and photophysics, for pharmaceuticals and agrochemicals will undoubtedly be forthcoming. Admittedly, this brief overview cannot cover the huge diversity of recently introduced ruthenium complexes and concentrates essentially on concepts and trends disclosed during 2013-2014 and early 2015. A critical appraisal of these aspects is presented showcasing Ru-driven advances in anticancer chemotherapy, medicinal applications, catalysis, water oxidation, photoactive complexes, functional and nanomaterials and complex design that have newly taken center stage.

\section{Ruthenium-Based Anticancer Drugs. Medicinal Applications}

Though started over 50 years ago, the development of metal anticancer drugs has traditionally focused on cytotoxic platinum compounds, several of which have reached clinical application [15]. The deeper understanding of cancer biology triggered the introduction of targeted chemotherapies, using other metal-based drugs, able to address specific cancer physiologies or disease states [16-19]. As most of the ruthenium complexes are less toxic than their platinum counterparts, this progress offers considerable added value for medical implementation. Although so far none of the ruthenium complexes are in clinical use as anticancer drugs, the remarkable success in clinical trials of NAMI-A, KP1019, and KP1339, combined with abundant reports on the enhanced in vitro and in vivo activity of other types of ruthenium complexes, prompted ruthenium chemotherapeutics to rapidly become a major area in anticancer drug advancement [20-26]. In an illustrative example NAMI-A, inactive against primary tumors but specifically targeting tumor metastases, was shown to display an improved antimetastatic activity when turned into macromolecular NAMI-A, a biocompatible amphiphilic block copolymer forming micelles that increase the cytotoxicity and cell uptake of the drug [22]. In the search for superior metallodrugs, ruthenium chemistry is taking momentum through the introduction of Ru-containing macromolecular complexes (dendrimers, dendronized polymers, protein conjugates, intelligent nanoparticles for advanced drug delivery, and polymer Ru-complex conjugates) that better differentiate between tumor cells and healthy cells [26].

Currently considered among the most promising alternatives to platinum drugs, active by interaction with DNA, ruthenium complexes also operate via different mechanisms [27-33]. Both $\mathrm{Ru}(\mathrm{II})$ and $\mathrm{Ru}$ (III) oxidation states are stable in physiological solutions, with the latter considered to be less reactive; therefore, $\mathrm{Ru}$ complexes are generally reported to act as redox-activatable prodrugs [34,35]. Recent research largely illustrates that the in vitro and in vivo properties of ruthenium compounds can be finely tuned by ligand variation. Intense investigations converge on ligand selection from the arene, phosphine, aromatic heterocycles, pyridine, pta, pybox, pyrazolone-based $\beta$-ketoamine, nitrosyl, Schiff-base, carboxamide, carbothioamide, thiourea, thiocarbamate, thiosemicarbazone, and hydrazone classes [36-78]. Innovations were applied to construct coordination-driven self-assembled arene-Ru metalla-rectangles endowed with stronger cytotoxicity against all cancer cell lines and even more effective than established anticancer drugs like doxorubicin and cisplatin [50]. That interest in the bioactivity profiles 
of ruthenium complexes has grown rapidly is amply demonstrated by design of new Ru compounds inhibiting enzymes, by the novel multinuclear systems acting as drug delivery vehicles or imaging and theranostics agents and signal transduction elements. A major contribution came as well from the advent of refined bioanalytical, biophysical and spectroscopic techniques used to elucidate the structure and the in vivo functioning of these complexes [79-100]. Some arene-functionalized dinuclear organometallic $\mathrm{Ru}(\mathrm{II})$ complexes are capable of crosslinking model peptide and oligonucleotide sequences while cytotoxicities are linked to their more rigid or more flexible conformations [81]. The mechanism of action of ruthenium-based antitumor drugs was studied, especially in regard to the capacity of ruthenium to mimic iron in its binding to biological molecules. Along these lines, new ruthenium complexes containing the enantiopure ligands 2,6-bis $\left[4^{\prime}(R)\right.$ phenyloxazolin-2'-yl-pyridine $\quad((R, R)$-Ph-pybox $), \quad 2,6$-bis[4' $(S)$-isopropyloxazolin-2'-yl-pyridine $]$ $((S, S)$-iPr-pybox $)$ or 2,6-bis[4' $(R)$-isopropyloxazolin-2'-yl-pyridine] $((R, R)$-iPr-pybox $)$ and the water soluble 1,3,5-triaza-7-phosphaadamantane (PTA) or $N$-substituted PTA phosphanes, have been synthesized. Their interactions with plasmidic DNA and cytotoxic activities against human cervical cancer HeLa cell lines have been evaluated, evidencing the distinct ability of the enantiomeric ligands in affecting the cell cycle of HeLa tumor cells [101].

Incorporation of biologically-derived ligands that primarily aim at minimizing toxicity toward normal cells is a viable avenue for engineering ruthenium complexes since they provide ways to improve antiproliferative activity of metal-based drugs [102]. Such ligands display different coordination modes, facilitate compatibility of the complex with the biological environment, and promote a higher cellular uptake. The diversity of bio-relevant ligands installed as essential components of ruthenium complexes ranges from amino acids, peptides, proteins, carbohydrates, purine bases and oligonucleotides to steroids and other bioactive entities endowed with specific properties [103-108]. This methodology is confirmed by excellent studies on Ru complexes that open unique opportunities for rational design and production of potent ruthenium anticancer drugs tackling distinct transport pathways and mechanisms of action [108,109].

Photoactivation of ruthenium complexes for triggering and/or modulating their antitumor activity [110-113] is presently of great interest. The process enables transformation of unreactive $\mathrm{Ru}(\mathrm{II})$ complexes into light-driven cytotoxic species [114] that can subsequently interact with proteins and DNA at the cellular level. In some representative examples, it has been demonstrated that, using a clinical grade photodynamic therapy laser source, red-to-blue upconverting liposomes were capable of triggering photodissociation of ruthenium polypyridyl complexes from PEGylated liposomes [115]. Several ruthenium(II) polypyridyl complexes have been elaborated to act as two-photon absorption (TPA) agents in mitochondria-targeted photodynamic therapy, a promising new technique for resolving tumors selectively and subduing resistance to alternative anticancer therapies [116]. Cellular toxicity induced by photorelease of certain bioactive molecules has been proved as a valid alternative for Ru photodynamic therapeutic agents (PDT) with dual-action [117-119].

When photoactivated, surface-grafted ruthenium complexes on mesoporous silica nanoparticles undergo photoexpulsion and subsequent release as cytotoxic entities toward cancer cells [120]. Nowadays, numerous accounts on photoactivatable $\mathrm{Ru}(\mathrm{II})$ complexes that exhibit different types of biologically relevant activities have been published [121-125]. Of real consequence for therapeutic purposes, catalytic reactions induced in cells by certain metallodrugs pertaining to the class of redox 
modulators or photosensitizers may ensure low-dose therapy protocols [126]. An interesting catalytic procedure demonstrated that transfer hydrogenation promoted by Noyori-type ruthenium complexes can reduce coenzyme $\mathrm{NAD}^{+}$to $\mathrm{NADH}$ in human ovarian cancer cells by using non-toxic concentrations of formate as a hydride donor source [127]. Such advanced catalytic processes enhance capabilities of ruthenium complexes, while also increasing selectivity towards cancer cells versus normal cells.

Ruthenium complexes additionally find important medicinal applications as NO carriers and donors for induction of vascular relaxation (some $\mathrm{Ru}$ (III) complexes can act as nitric oxide scavengers thus improving graft survival). Drugs based on specific Ru complexes are active against parasitic diseases (e.g., leishmanicidal and protozoanicidal agents), as antibacterial, antifungal and anticorrosion additives in coatings on Ti-alloys used in medical devices [128-134].

\section{Ruthenium Complexes in Catalysis}

Unquestionably, the second major area of overwhelming importance is catalysis promoted by $\mathrm{Ru}$ complexes, as also recognized by the Nobel Prizes awarded for the field. Productive catalytic applications of these complexes embrace a broad variety of chemical transformations, have known tremendous recent progress, while some are valorized on large scale, have true industrial perspectives or have already been industrialized [135]. Noteworthy, environmentally friendly homogeneous and immobilized ruthenium catalysts enabled indispensable synthetic methods inaccessible with other metal-based catalytic systems. With the aim of upgrading versatility of the ruthenium-based catalysis, new mononuclear, binuclear and polynuclear ruthenium complexes with arene, phosphine, phosphite, BINAP, alkylidene, vinylidene, allenylidene, indenylidene, $N$-heterocyclic carbene (NHC), cyclic alkyl amino carbene (CAAC), porphyrin, pincer, Schiff-base, polydentated and polycyclic ligands have continued to be prepared, minutely characterized and explored in chemoselective catalytic processes [136-158]. In an innovatory undertaking, graphene oxide was used to support ruthenium catalysts in order to activate self-healing in multifunctional materials that are able to simultaneously integrate the healing process with the advantageous properties of graphene-based materials [159]. Part of a large body of work concerns fundamental reactions studied anew with $\mathrm{Ru}$ complexes including hydrogenation and transfer hydrogenation; oxidation and hydroxylation; $\mathrm{C}-\mathrm{C}, \mathrm{C}-\mathrm{X}$ and $\mathrm{N}-\mathrm{X}$ bond formation; olefin metathesis and related $\mathrm{C}-\mathrm{C}$ couplings; alkylation; arylation; isomerization; epimerization; condensation; cyclization; atom transfer radical reactions; oligomerization and polymerization [160-193]. Among non-metathetical reactions, the versatile and easy to handle transfer hydrogenation is often chosen as standard method for appraising and comparing the catalytic activity of ruthenium promoters [167-173].

In the chase for renewable energy sources currently in high demand, hydrogen resulting from electrochemical water splitting has been proposed as an energy carrier. Not long ago, an ingenuous method for hydrogen storage has been disclosed. The process, based on a $\mathrm{CO}_{2}\left(\mathrm{HCO}_{3}{ }^{-}\right) / \mathrm{H}_{2}$ and formate equilibrium within an amine-free reversible system is catalyzed by commercially available Ru pincer complexes and produces an advantageous mixture of $\mathrm{H}_{2}$ ( $\mathrm{CO}$ free) and $\mathrm{CO}_{2}$ [194]. As a valuable addition to the multiple Ru-based catalyses, bond activations and functionalizations (e.g. $\mathrm{H}-\mathrm{H}, \mathrm{C}-\mathrm{H}$, N-H, O-H, B-H, and $\mathrm{Si}-\mathrm{H}$ ) have been explored [195-198]. 
Stereoselective oxidative reactions of a host of functional groups, more specifically asymmetric epoxidation of alkenes, dihydroxylation of olefins, oxidative dehydrogenation of alcohols and generation of dioxygen species, have also been addressed using diverse ruthenium catalysts [199]. For example, a recent communication clearly evidenced that $\mathrm{Ru}$-aqua complex $\left\{\left[\mathrm{Ru}^{\mathrm{II}}(\operatorname{trpy})\left(\mathrm{H}_{2} \mathrm{O}\right)\right]_{2}(\mu-p y r-\mathrm{dc})\right\}^{+}$can be a powerful epoxidation catalyst for a wide range of linear and cyclic alkenes [200].

A subject of renewed interest is presently the production of oxygen through water splitting by help of $\mathrm{Ru}$ catalysts as showcased in excellent reviews [201-203]. Mononuclear and binuclear ruthenium complexes have been explored in this reaction outlining the influence of monodentate and polydentate ligands on the course of water oxidation [204-212]. In the opposite process, water reduction, conducted with polydentated $\mathrm{Ru}$ catalysts, the solar $\mathrm{H}_{2}$ production was coupled to photoinitiated electron collection in polyazine chromophores [213].

One recent refined approach applies $\mathrm{Ru}(\text { bpy })_{3} \mathrm{Cl}_{2}$ as photoredox catalyst and $p$-toluidine as redox mediator in the visible light photocatalytic thiol-ene "click" reaction for fast polymer post-functionalization and step-growth polymerization, under aerobic conditions [214].

Schiff-base (e.g. Salen) Ru-complexes enable versatile asymmetric catalysis for a range of chemical transformations, especially for carbene, nitrene, and oxene transfer reactions [11,146,215,216]. Complexes of this class reportedly serve as catalysts for oxidation/epoxidation, with chiral $\mathrm{Ru}$-complexes such as Ru-porphyrin, desymmetric Ru-Schiff base and Ru-bisamide complexes being employed in asymmetric epoxidation. Importantly, $\left(\mathrm{ON}^{+}\right)$(Salen)ruthenium(II) complexes were found to catalyze epoxidation of conjugated olefins under light irradiation. In some instances, these olefins showed high enantioselectivity, greater than $80 \%$ ee, irrespective of their substitution pattern.

Latterly, vast research centers on the functionalization of diverse organic substrates as promoted by ruthenium catalysts. For instance, alkynylation of aldehydes, hydroacylation, hydroboration and hydrosilylation of terminal alkynes, conjugate addition of alkynes to $\alpha, \beta$-unsaturated carbonyl compounds, enantioselective carbonyl allylation, decarbonylation of acetone and carbonate, $N$-formylation of amines and reduction of hydrazine to ammonia (occurring with high chemoselectivity) have been tackled [198,217-224]. Racemization of sec-alcohols catalyzed by homogeneous half-sandwich ruthenium complexes $\left(\mathrm{Cp} * \mathrm{Ru}(\mathrm{CO})_{2} \mathrm{Cl}\right)$ has been newly examined [225-227]; under the influence of the ruthenium catalyst, only the hydroxyl-substituted stereocenter was interconverted occasionally, making epimerization analogous to racemization. Computational investigations on $\mathrm{CO}$ dissociation within cyclopentadienyl ruthenium complexes, relevant to the racemization of alcohols, have been carried out as well [228]. For the 16- and 18-electron $p$-cymene ruthenium complexes, the ligand dissociation effect in racemization and dynamic kinetic resolution of alcohols was appraised [229]. A cationic ruthenium complex for the efficient dynamic kinetic resolution of secondary alcohols has also been communicated [230].

With introduction of the new generations of highly active and chemoselective Ru metathesis catalysts endowed with high tolerance towards many functionalities and good stability in the presence of air, moisture and various solvents, including water-containing systems [231-239], the diversification of metathesis reactions experienced a strong impetus [240-245]. Among metathesis reactions, cross-metathesis (CM) [246-249] and ring-closing metathesis (RCM) [250-254] have become the most encountered strategies for the synthesis of linear and branched, or carbocyclic and heterocyclic compounds. Ru-catalyzed enyne metathesis (EYRCM) provided an elegant and productive way to 
obtain small, medium and large cyclic molecules [255]. Numerous tandem metathesis protocols (RCM-CM, RCM-RCM, and RCM-ROM-CM), as well as related processes (C-C coupling, cyclopropanation, cyclizations, and polymerizations) facilitated the synthesis of complex organic molecules, intermediates for fine chemicals, bioactive natural products, macrocyclic or polycyclic structures, functional polymers and supramolecular architectures [256-264]. Intricate scaffolds for pharmaceuticals and agrochemicals have been accessed by these advanced strategies [265-267]. In a short time total syntheses, involving key metathesis steps (mostly RCM or EYRCM) were competitively advanced by different groups, providing an elegant and easier access to a plethora of complex bioactive molecules that display antitumor, antiviral, anti-HIV, antimicrobial, antifungal activities, and also to alkaloids and other classes of naturally occurring compounds [260,261,268]. More particular cases like metathesis-based syntheses of a range of iminosugars, and bioactive iriomoteolide and kendomycin were given special attention [269-273]. Synthesis, involving enyne metathesis, of biologically and medicinally significant molecules like $(+)$-anatoxin-A, $(+)$-anthramycin, artemisinin, transtaganolide $\mathrm{D}$, allo-colchicine, (-)-galanthamine, (-)-longithorone A, (+)-ochromycinone, (+)-rubiginone B2, and $(-)$-stemoamide have become attractive when starting from adequate substrates [274]. It should be emphasized that cross-metathesis allowed diversification of synthetic strategies by employing substrates that are tolerated by the new generations of $\mathrm{Ru}$ complexes [231,236-239,243,244,246-249]. A remarkably creative work encompasses the total synthesis of (-)-amphidinolide $\mathrm{K}$ and $\mathrm{V}$ applying an ingenious combination of Mo with Ru metathesis catalytic systems [275].

Ring-opening metathesis polymerization (ROMP) of monocyclic, bicyclic and polycyclic monomers with $\mathrm{Ru}$ complexes [276-279] unveiled polymerization methodologies capable to deliver unique materials not available by conventional polymerization techniques [280-285]. New types of telechelic and supramolecular polymers have been obtained by devising ruthenium catalysts suitable for their synthesis [286,287]. Ru complexes also intervene in acyclic diene metathesis polymerization (ADMET) [288,289] and polymerization of substituted acetylenes [290]. Not long ago, novel synthetic procedures based on ruthenium catalysis extended the range of biologically active polymers, biorenewable polymers and biodegradable copolymers [291-293].

Materials science took advantage of the contemporary capabilities of $\mathrm{Ru}$ complexes in inventive applications destined for industrial technologies. Thus, syntheses of nanoparticles and materials with nanostructured periodicity have been elaborated [294,295]. Polydicyclopentadiene (pDCPD) aerogels, obtained via ROMP, that are low-density nanostructured nanoporous solids with high surface-to-volume ratios, target applications including thermal and acoustic insulation, porous membranes, superhydrophobic surfaces and antireflection coatings [296]. Nanostructures based on gold-anchored ROMP polymers were introduced as valuable materials for microelectronics, catalysis and optophysics.

With the purpose of enhancing the photovoltaic performance of solar cells, different research groups have attempted to modify the structure of the coordinated chromophoric and ancillary ligands of ruthenium-based dye sensitizers [297-300]. For example, though initially ruthenium(II) complexes used in luminescent applications such as dye-sensitized solar cells incorporated only poly-pyridine, poly-azolium or other poly- $N$-heterocyclic moieties, of late NHC substituents have also been added to give rise to the high energy emissions required for OLED devices [301]. In this new context, it has been shown that the free rotation in polypyridine ligands of $\mathrm{Ru}(\mathrm{II})$ complexes induces a substantial effect on the performance of light-emitting electrochemical cells [302]. Advanced research on the 
electrochemical, photochromic, photovoltaic and redox properties of a variety of ruthenium complexes opens further perspectives of applications of ruthenium complexes, depending on their substitution pattern [303-305].

Sophisticated dendritic motifs have been made available for chemical sensors, electronic devices and catalytic reactions [306-309]. Multifunctional organometallic polymers obtained by ROMP in the presence of $\mathrm{Mo}$ and $\mathrm{Ru}$ complexes found interesting valorization in conducting materials and catalysis [310-313]. In a recent, very elegant work, it was demonstrated that mixed-valent "click" intertwined polymer units, containing biferrocenium chloride side chains, obtained by ROMP or radical chain reactions, form nanosnakes that encapsulate gold nanoparticles [314]. Worth notice is that polymers containing triazolylbiferrocenyl groups in the side or in the main chain, synthesized by ROMP, radical or "click" cycloaddition reactions, could be oxidized by [ $\left.\mathrm{FeCp}_{2}\right]\left[\mathrm{PF}_{6}\right], \mathrm{H}\left[\mathrm{AuCl}_{4}\right]$, or $\mathrm{Ag}\left[\mathrm{BF}_{4}\right]$ to form stable triazolylbiferrocenium salts. Various $\mathrm{Au}$ and $\mathrm{Ag}$ nanoparticle networks were stabilized by these biferrocenium salts providing modified electrodes suitable for chemical sensing [315]. Elaborated bifunctional copolymers electrogenerated from pyrenebutyric acid, $N \alpha^{\prime}, N \alpha$-bis(carboxymethyl)L-lysine amide (NTA-pyrene) and, as a third component, the [tris-(2,2'-bipyridine)(4,4'-bis(4-pyrenyl-1ylbutyloxy)-2,2'-bipyridine] ruthenium(II) hexafluorophosphate complex (Ru(II)-pyrene) allowed bioreceptor immobilization and transduction of biorecognition events. Such label-free photoelectrochemical immunosensors and aptasensors were applied to the determination of thrombin and the anti-cholera toxin antibody [316].

\section{Ruthenium Complexes in Sustainable Processes}

This brief account could not be concluded without signaling at least a part of the newly acquired relevance of ruthenium complexes for industrial valorization [317-319]. As seen from this overview, $\mathrm{Ru}$ complexes contribute to sustainability through conservation of fossil resources and energy. Thus, oleochemisty by means of ruthenium catalysis, a field of major interest and presently intensively explored, is producing value-added synthetic products such as olefins, polymer additives, surface coatings, pharmaceuticals, etc. from natural seed oil feedstocks largely available in many countries. By a metathesis-based technology, palm oil and jojoba oil can be used to make high performance olefins and other specialty chemicals for a wide range of applications, including surfactants, detergents, lubricants, and biofuels [320,321]. A representative example of metathesis starting from renewable raw materials is self-metathesis of methyl oleate and cross-metathesis of methyl oleate with (Z)-2-butene-1,4-diol diacetate promoted by a series of indenylidene Ru catalysts [322]. A versatile ring-closing metathesis process has been developed for the synthesis of polyamide (nylon) precursors of various chain-lengths (PA11, 12, and 13); the technology allows an economical and sustainable production of these polymers from oleic acid as a single starting material [323]. Furthermore, a highly chemoselective procedure for obtaining valuable alcohols and higher-oxidation-state compounds by catalytic $Z$-selective cross-metathesis holds promise for a future application on a large scale [324]. In a patented procedure for valorization of biomass materials, cellulose was saccharified using a Ru catalyst supported on carbonized cellulose containing $\mathrm{SO}_{3} \mathrm{H}$ groups to give glucose in a $40 \%$ yield, at $68 \%$ cellulose conversion [325]. Cross-metathesis of bio-sourced fatty nitriles with acrylonitrile provides an efficient way for conservation of natural resources [326]. 
Along quite different lines, alkenones, abundantly found in oceans, having chains of 37-39 carbon atoms, could be broken by olefin metathesis into 8-13 C-atom chains, thus becoming useful for jet fuel [327]. A newly disclosed invention employs Proxima (a thermoset resin for glass and carbon fiber reinforced composites, produced via olefin metathesis with Grubbs' catalyst) to reduce the amount of carbon fiber required in hydrogen pressure vessels lowering in this way the cost of hydrogen storage tanks [328].

An important aspect in the industrial valorization of $\mathrm{Ru}$ complexes is the removal of ruthenium residues, mandatory in areas where the level of this heavy metal in the final products (pharmaceuticals, specialty polymers designed for food supplies, and biomedical, textile or electronic applications) could be problematic for human health [329]. Overall, the high potential and versatility of the Ru complexes attest to the importance they assume in chemistry and other scientific and technical areas and undoubtedly ensure the emergence, in the near future, of further developments serving mankind.

The valuable contributions from the authors of this Special Issue "Ruthenium Complex" of Molecules are highly appreciated. Special thanks are due to the reviewers of the papers as well as to the members of the editorial staff of Molecules for their initiative for this Special Issue and their kind cooperation during the editorial process. We hope the readers will benefit from the diverse facets of the chemistry and applications of ruthenium complexes, included in this Special Issue, that largely illustrate the newest trends in the field.

\section{Acknowledgments}

The authors gratefully acknowledge support from the Institute of Organic Chemistry of the Romanian Academy (I.D. \& V.D.) and Department of Chemistry, University of Liège (A.D.).

\section{Conflicts of Interest}

The authors declare no conflict of interest.

\section{References}

1. Storr, T. Ligand Design in Medicinal Inorganic Chemistry; John Wiley \& Sons, Ltd.: Chichester, UK, 2014.

2. Crabtree, R.H. The Organometallic Chemistry of the Transition Metals, 6th ed.; John Wiley \& Sons, Inc.: Hoboken, NJ, USA, 2014.

3. Gade, L.H.; Hofmann, P. Molecular Catalysts: Structure and Functional Design; Wiley-VCH: Weinheim, Germany, 2014.

4. Wang, D.; Astruc, D. Fast-growing field of magnetically recyclable nanocatalysts. Chem. Rev. 2014, 114, 6949-6985.

5. Prier, C.K.; Rankic, D.A.; MacMillan, D.W.C. Visible light photoredox catalysis with transition metal complexes: Applications in organic synthesis. Chem. Rev. 2013, 113, 5322-5363.

6. Strasser, S.; Pump, E.; Fischer, R.C.; Slugovc, C. On the chloride lability in electron-rich second-generation ruthenium benzylidene complexes. Monatsh. Chem. 2015, 146, 1143-1151. 
7. Gunanathan, C.; Milstein, D. Bond activation and catalysis by ruthenium pincer complexes. Chem. Rev. 2014, 114, 12024-12087.

8. Tönnemann, J.; Scopelliti, R.; Severin, K. (Arene)ruthenium complexes with imidazolin-2-imine and imidazolidin-2-imine ligands. Eur. J. Inorg. Chem. 2014, 2014, 4287-4293.

9. Ablialimov, O.; Kędziorek, M.; Malińska, M.; Woźniak, K.; Grela, K. Synthesis, structure, and catalytic activity of new ruthenium(II) indenylidene complexes bearing unsymmetrical $N$-heterocyclic carbenes. Organometallics 2014, 33, 2160-2171.

10. Mukherjee, T.; Ganzmann, C.; Bhuvanesh, N.; Gladysz, J.A. Syntheses of enantiopure bifunctional 2-guanidinobenzimidazole cyclopentadienyl ruthenium complexes: Highly enantioselective organometallic hydrogen bond donor catalysts for carbon-carbon bond forming reactions. Organometallics 2014, 33, 6723-6737.

11. Dragutan, I.; Dragutan, V.; Verpoort, F. Carbenoid transfer in competing reactions catalyzed by ruthenium complexes. Appl. Organomet. Chem. 2014, 28, 211-215.

12. Biffis, A.; Baron, M.; Tubaro, C. Poly-NHC Complexes of transition metals: Recent applications and new trends. Adv. Organomet. Chem. 2015, 63, 203-288.

13. Ivry, E.; Ben-Asuly, A.; Goldberg, I.; Lemcoff, N.G. Amino acids as chiral anionic ligands for ruthenium based asymmetric olefin metathesis. Chem. Commun. 2015, 51, 3870-3873.

14. Carreira, E.M.; Yamamoto, H. Synthetic Methods III-Catalytic Methods: C-C Bond Formation. In Comprehensive Chirality; Elsevier: Amsterdam, The Netherlands, 2012; Volume 4.

15. Wilson, J.J.; Lippard, S.J. Synthetic methods for the preparation of platinum anticancer complexes. Chem. Rev. 2014, 114, 4470-4495.

16. Muhammad, N.; Guo, Z. Metal-based anticancer chemotherapeutic agents. Curr. Opin. Chem. Biol. 2014, 19, 144-153.

17. Medici, S.; Peana, M.; Nurchi, V.M.; Lachowicz, J.I.; Crisponi, G.; Zoroddu, M.A. Noble metals in medicine: Latest advances. Coord. Chem. Rev. 2015, 284, 329-350.

18. Trudu, F.; Amato, F.; Vaňhara, P.; Pivetta, T.; Peña-Méndez, E.M.; Havel, J. Coordination compounds in cancer: Past, present and perspectives. J. Appl. Biomed. 2015, 13, 79-103.

19. Ramu, W.; Gill, M.R.; Jarman, P.J.; Turton, D.; Thomas, J.A.; Das, A.; Smythe, C. A cytostatic ruthenium(II)-platinum(II) bis(terpyridyl) anticancer complex that blocks entry into S phase by up-regulating p27 ${ }^{\mathrm{KIP} 1}$. Chem. Eur. J. 2015, 21, 9185-9197.

20. Bergamo, A.; Sava, G. Linking the future of anticancer metal-complexes to the therapy of tumour metastases. Chem. Soc. Rev. 2015, doi:10.1039/c5cs00134j

21. Motswainyana, W.M.; Ajibade, P.A. Anticancer activities of mononuclear ruthenium(II) coordination complexes. Adv. Chem. 2015, 1-21, doi:10.1155/2015/859730.

22. Blunden, B.M.; Rawal, A.; Lu, H.; Stenzel, M.H. Superior chemotherapeutic benefits from the ruthenium-based anti-metastatic drug NAMI-A through conjugation to polymeric micelles. Macromolecules 2014, 47, 1646-1655.

23. Bergamo, A.; Riedel, T.; Dyson, P.J.; Sava, G. Preclinical combination therapy of the investigational drug NAMI-A(+) with doxorubicin for mammary cancer. Invest. New Drugs 2015, 33, 53-63. 
24. Trondl, R.; Heffeter, P.; Kowol, C.R.; Jakupec, M.A.; Berger, W.; Keppler, B.K. NKP-1339, the first ruthenium-based anticancer drug on the edge to clinical application. Chem. Sci. 2014, 5, 2925-2932.

25. Dömötör, O.; Hartinger, C.G.; Bytzek, A.K.; Kiss, T.; Keppler, B.K.; Enyedy, E.A. Characterization of the binding sites of the anticancer ruthenium(III) complexes KP1019 and KP1339 on human serum albumin via competition studies. J. Biol. Inorg. Chem. 2013, 18, 9-17.

26. Valente, A.; Garcia, M.H. Syntheses of macromolecular ruthenium compounds: A new approach for the search of anticancer drugs. Inorganics 2014, 2, 96-114.

27. Spreckelmeyer, S.; Orvig, C.; Casini, A. Cellular transport mechanisms of cytotoxic metallodrugs: An overview beyond cisplatin. Molecules 2014, 19, 15584-15610.

28. Adhireksan, Z.; Davey, G.E.; Campomanes, P.; Groessl, M.; Clavel, C.M.; Yu, H.; Nazarov, A.A.; Yeo, C.H.F.; Ang, W.H.; Dröge, P.; et al. Ligand substitutions between ruthenium-cymene compounds can control protein versus DNA targeting and anticancer activity. Nat. Commun. 2014, 5, 3462, doi:10.1038/ncomms4462.

29. Nazarov, A.A.; Gardini, D.; Baquié, M.; Juillerat-Jeanneret, L.; Serkova, T.P.; Shevtsova, E.P.; Scopelliti, R.; Dyson, P.J. Organometallic anticancer agents that interfere with cellular energy processes: A subtle approach to inducing cancer cell death. Dalton Trans. 2013, 42, 2347-2350.

30. Nazarov, A.A.; Meier, S.M.; Zava, O.; Nosova, Y.N.; Milaeva, E.R.; Hartinger, C.G.; Dyson, P.J. Protein ruthenation and DNA alkylation: Chlorambucil-functionalized RAPTA complexes and their anticancer activity. Dalton Trans. 2015, 44, 3614-3623.

31. Sharma, A.R.; Gangrade, D.M.; Bakshi, S.D.; John, J.S. Ruthenium complexes: Potential candidate for anti-tumour activity. Int. J. Chem. Tech. Res. 2014, 6, 828-837.

32. Guidi, F.; Modesti, A.; Landini, I.; Nobili, S.; Mini, E.; Bini, L.; Puglia, M.; Casini, A.; Dyson, P.J.; Gabbiani, C.; et al. The molecular mechanisms of antimetastatic ruthenium compounds explored through DIGE proteomics. J. Inorg. Biochem. 2013, 118, 94-99.

33. Wu, K.; Luo, Q.; Hu, W.; Li, X.; Wang, F.; Xiong, S.; Sadler, P.J. Mechanism of interstrand migration of organoruthenium anticancer complexes within a DNA duplex. Metallomics 2012, 4, $139-148$.

34. Lippard, S.J.; Graf, N. Redox activation of metal-based prodrugs as a strategy for drug delivery. Adv. Drug Deliv. Rev. 2012, 64, 993-1004.

35. Lee, H.Z.S.; Buriez, O.; Labbé, E.; Top, S.; Pigeon, P.; Jaouen, G.; Amatore, C.; Leong, W.K. Oxidative sequence of a ruthenocene-based anticancer drug candidate in a basic environment. Organometallics 2014, 33, 4940-4946.

36. Srinivasarao, M.; Galliford, C.V.; Low, P.S. Principles in the design of ligand-targeted cancer therapeutics and imaging agents. Nat. Rev. Drug Discov. 2015, 14, 203-219.

37. Saez, R.; Lorenzo, J.; Prieto, M.J.; Font-Bardia, M.; Calvet, T.; Omenaca, N.; Vilaseca, M.; Moreno, V. Influence of $\mathrm{PPh}_{3}$ moiety in the anticancer activity of new organometallic ruthenium complexes. J. Inorg. Biochem. 2014, 136, 1-12.

38. De C. Pereira, F.; Lima, B.A.V.; de Lima, A.P.; Pires, W.C.; Monteiro, T.; Magalhaes, L.F.; Costa, W.; Graminha, A.E.; Batista, A.A.; Ellena, J.; et al. cis-[RuCl(BzCN)(N-N)(P-P)]PF6 Complexes: Synthesis and in vitro antitumor activity. J. Inorg. Biochem. 2015, 149, 91-101. 
39. Singh, A.K.; Pandey, D.S.; Xu, Q.; Braunstein, P. Recent advances in supramolecular and biological aspects of arene ruthenium(II) complexes. Coord. Chem. Rev. 2014, 270-271, 31-56.

40. Süss-Fink, G. Water-soluble arene ruthenium complexes: From serendipity to catalysis and drug design. J. Organomet. Chem. 2014, 751, 2-19.

41. Martin, E.K.; Pagano, N.; Sherlock, M.E.; Harms, K.; Meggers, E. Synthesis and anticancer activity of ruthenium half-sandwich complexes comprising combined metal centrochirality and planar chirality. Inorg. Chim. Acta 2014, 423, 530-539.

42. Pastuszko, A.; Niewinna, K.; Czyz, M.; Józwiak, A.; Malecka, M.; Budzisz, E. Synthesis, X-ray structure, electrochemical properties and cytotoxic effects of new arene ruthenium(II) complexes. J. Organomet. Chem. 2013, 745-746, 64-70.

43. Kilpin, K.J.; Cammack, S.M.; Clavel, C.M.; Dyson, P.J. Ruthenium(II) arene PTA (RAPTA) complexes: Impact of enantiomerically pure chiral ligands. Dalton Trans. 2013, 42, 2008-2014.

44. Weiss, A.; Berndsen, R.H.; Dubois, M.; Muller, C.; Schibli, R.; Griffioen, A.W.; Dyson, P.J.; Nowak-Sliwinska, P. In vivo anti-tumor activity of the organometallic ruthenium(II)-arene complex $\left[\mathrm{Ru}\left(\eta^{6}-p\right.\right.$-cymene) $\mathrm{Cl}_{2}$ (pta) $]$ (RAPTA-C) in human ovarian and colorectal carcinomas. Chem. Sci. 2014, 5, 4742-4748.

45. Govender, P.; Sudding, L.C.; Clavel, C.M.; Dyson, P.J.; Therrien, B.; Smith, G.S. The influence of RAPTA moieties on the antiproliferative activity of peripheral-functionalised poly(salicylaldiminato) metallodendrimers. Dalton Trans. 2013, 42, 1267-1277.

46. Clavel, C.M.; Păunescu, E.; Nowak-Sliwinska, P.; Griffioen, A.W.; Scopelliti, R.; Dyson, P.J. Discovery of a highly tumor-selective organometallic ruthenium(II)-arene complex. J. Med. Chem. 2014, 57, 3546-3558.

47. Wang, Z.; Qian, H.; Yiu, S.-M.; Sun, J.; Zhu, G. Multi-targeted organometallic ruthenium(II)-arene anticancer complexes bearing inhibitors of poly(ADP-ribose) polymerase-1: A strategy to improve cytotoxicity. J. Inorg. Biochem. 2014, 131, 47-55.

48. Nazarov, A.A.; Hartinger, C.G.; Dyson, P.J. Opening the lid on piano-stool complexes: An account of ruthenium(II) arene complexes with medicinal applications. J. Organomet. Chem. 2014, 751, 251-260.

49. Clavel, C.M.; Păunescu, E.; Nowak-Sliwinska, P.; Dyson, P.J. Thermoresponsive organometallic arene ruthenium complexes for tumour targeting. Chem. Sci. 2014, 5, 1097-1101.

50. Mishra, A.; Jeong, Y.J.; Jo, J.-H.; Kang, S.C.; Kim, H.; Chi, K.-W. Coordination-driven self-assembly and anticancer potency studies of arene-ruthenium-based molecular metallarectangles. Organometallics 2014, 33, 1144-1151.

51. Lai, H.; Zhao, Z.; Li, L.; Zheng, W.; Chen, T. Antiangiogenic ruthenium(II) benzimidazole complexes, structure-based activation of distinct signaling pathways. Metallomics 2015, 7, 439-447.

52. Franco, D.; Vargiu, A.V.; Magistrato, A. Ru[(bpy) $2(\mathrm{dppz})]^{2+}$ and $\mathrm{Rh}\left[(\mathrm{bpy})_{2} \text { (chrysi) }\right]^{3+}$ targeting double strand DNA: The shape of the intercalating ligand tunes the free energy landscape of deintercalation. Inorg. Chem. 2014, 53, 7999-8008.

53. Huang, H.; Zhang, P.; Chen, H.; Ji, L.; Chao, H. Comparison between polypyridyl and cyclometallated ruthenium(II) complexes: Anticancer activities against 2D and 3D cancer models. Chem. Eur. J. 2015, 21, 715-725. 
54. Vyas, N.A.; Bhat, S.S.; Kumbhar, A.S.; Sonawane, U.B.; Jani, V.; Joshi, R.R.; Ramteke, S.N.; Kulkarni, P.P.; Joshi, B. Ruthenium(II) polypyridyl complex as inhibitor of acetylcholinesterase and A $\beta$ aggregation. Eur. J. Med. Chem. 2014, 75, 375-381.

55. Xiao, L.; Wang, H.; Zhang, Q.; Zhu, Y.; Luo, J.; Liang, Y.; Zhang, S.; Zhou, H.; Tian, Y.; Wu, J. Novel ruthenium(II) polypyridyl complexes containing carbazole with flexible substituents: Crystal structure, nonlinear optical properties and DNA-binding interaction. Dyes Pigments 2015, 113, 165-173.

56. Sun, D.; Zhang, W.; Yang, E.; Li, N.; Liu, H.; Wang, W. Investigation of antibacterial activity and related mechanism of a ruthenium(II) polypyridyl complex. Inorg. Chem. Commun. 2015, $56,17-21$.

57. Chellan, P.; Land, K.M.; Shokar, A.; Au, A.; An, S.H.; Taylor, D.; Smith, P.J.; Riedel, T.; Dyson, P.J.; Chibale, K.; et al. Synthesis and evaluation of new polynuclear organometallic $\mathrm{Ru}(\mathrm{II}), \mathrm{Rh}(\mathrm{III})$ and $\mathrm{Ir}(\mathrm{III})$ pyridyl ester complexes as in vitro antiparasitic and antitumor agents. Dalton Trans. 2014, 43, 513-526.

58. Kilpin, K.J.; Crot, S.; Riedel, T.; Kitchen, J.A.; Dyson, P.J. Ruthenium(II) and osmium(II) 1,2,3-triazolylidene organometallics: A preliminary investigation into the biological activity of “click” carbene complexes. Dalton Trans. 2014, 43, 1443-1448.

59. Kalaivani, P.; Prabhakaran, R.; Vaishnavi, E.; Rueffer, T.; Lang, H.; Poornima, P.; Renganathan, R.; Vijaya Padmad, V.; Natarajan, K. Synthesis, structure, DNA/protein binding and in vitro cytotoxicity of new ruthenium metallates. Inorg. Chem. Front. 2014, 1, 311-324.

60. Peña, B.; David, A.; Pavani, C.; Baptista, M.S.; Pellois, J.-P.; Turro, C.; Dunbar, K.R. Cytotoxicity studies of cyclometallated ruthenium(II) compounds: New applications for ruthenium dyes. Organometallics 2014, 33, 1100-1103.

61. Garza-Ortiz, A.; Maheswari, P.U.; Siegler, M.; Spek, A.I.; Reedijk, J. A new family of Ru(II) complexes with a tridentate pyridine Schiff-base ligand and bidentate co-ligands: Synthesis, characterization, structure and in vitro cytotoxicity studies. New J. Chem. 2013, 37, 3450-3460.

62. Garza-Ortiz, A.; Maheswari, P.U.; Lutz, M.; Siegler, M.A.; Reedijk, J. Tuning the cytotoxic properties of new ruthenium(III) and ruthenium(II) complexes with a modified bis(arylimino)pyridine Schiff base ligand using bidentate pyridine-based ligands. J. Biol. Inorg. Chem. 2014, 19, 675-689.

63. Chow, M.J.; Licona, C.; Wong, D.Y.Q.; Pastorin, G.; Gaiddon, C.; Ang, W.H. Discovery and investigation of anticancer ruthenium-arene Schiff-base complexes via water-promoted combinatorial three-component assembly. J. Med. Chem. 2014, 57, 6043-6059.

64. Ljubijankić, N.; Zahirović, A.; Turkušić, E.; Kahrović, E. DNA binding properties of two ruthenium(III) complexes containing Schiff bases derived from salicylaldehyde: Spectroscopic and electrochemical evidence of CT DNA intercalation. Croat. Chem. Acta 2013, 86, 215-222.

65. Koiri, R.K.; Trigun, S.K.; Mishra, L. Activation of p53 mediated glycolytic inhibition-oxidative stress-apoptosis pathway in Dalton's lymphoma by a ruthenium(II)-complex containing 4-carboxy $N$-ethylbenzamide. Biochimie 2015, 110, 52-61.

66. Mokesch, S.; Novak, M.S.; Roller, A.; Jakupec, M.A.; Kandioller, W.; Keppler, B.K. 1,3-Dioxoindan-2-carboxamides as bioactive ligand scaffolds for the development of novel organometallic anticancer drugs. Organometallics 2015, 34, 848-857. 
67. Donnici, C.L.; Nogueira, L.J.; Araujo, M.H.; Oliveira, S.R.; Magalhães, T.F.F.; Lopes, M.T.P.; Araújo e Silva, A.C.; da Costa Ferreira, A.M.; Martins, C.V.B.; de Resende Stoianoff, M.A. In vitro studies of the activity of dithiocarbamate organoruthenium complexes against clinically relevant fungal pathogens. Molecules 2014, 19, 5402-5420.

68. Enyedy, E.A.; Sija, E.; Jakusch, T.; Hartinger, C.G.; Kandioller, W.; Keppler, B.K.; Kiss, T. Solution equilibria of anticancer ruthenium(II)-( $\eta^{6}-p$-cymene)-hydroxy(thio)pyr(id)one complexes: Impact of sulfur vs. oxygen donor systems on the speciation and bioactivity. J. Inorg. Biochem. 2013, 127, 161-168.

69. Pettinari, R.; Pettinari, C.; Marchetti, F.; Clavel, C.M.; Scopelliti, R.; Dyson, P.J. Cytotoxicity of ruthenium arene complexes containing $\beta$-ketoamine ligands. Organometallics 2013, 32, 309-316.

70. Pettinari, R.; Marchetti, F.; Pettinari, C.; Petrini, A.; Scopelliti, R.; Clavel, C.M.; Dyson, P.J. Synthesis, structure, and antiproliferative activity of ruthenium(II) arene complexes with N,O-chelating pyrazolone-based $\beta$-ketoamine ligands. Inorg. Chem. 2014, 53, 13105-13111.

71. Pettinari, R.; Pettinari, C.; Marchetti, F.; Skelton, B.W.; White, A.H.; Bonfili, L.; Cuccioloni, M.; Mozzicafreddo, M.; Cecarini, V.; Angeletti, M.; et al. Arene-ruthenium(II) acylpyrazolonato complexes: Apoptosis-promoting effects on human cancer cells. J. Med. Chem. 2014, 57, 4532-4542.

72. Filak, L.K.; Kalinowski, D.S.; Bauer, T.J.; Richardson, D.R.; Arion, V.B. Effect of the piperazine unit and metal-binding site position on the solubility and anti-proliferative activity of ruthenium(II)and osmium(II)-arene complexes of isomeric indolo[3,2-c]quinoline-piperazine hybrids. Inorg. Chem. 2014, 53, 6934-6943.

73. Furrer, M.A.; Garci, A.; Denoyelle-Di-Muro, E.; Trouillas, P.; Giannini, F.; Furrer, J.; Clavel, C.M.; Dyson, P.J.; Süss-Fink, G.; Therrien, B. Synthesis, characterisation and in vitro anticancer activity of hexanuclear thiolato-bridged arene ruthenium metalla-prisms. Chem. Eur. J. 2013, 19, 3198-3203.

74. Khan, F.-A.; Therrien, B.; Süss-Fink, G.; Zava, O.; Dyson, P.J. Arene ruthenium dichloro complexes containing isonicotinic ester ligands: Synthesis, molecular structure and cytotoxicity. J. Organomet. Chem. 2013, 730, 49-56.

75. Meier, S.M.; Hanif, M.; Adhireksan, Z.; Pichler, V.; Novak, M.; Jirkovsky, E.; Jakupec, M.A.; Arion, V.B.; Davey, C.A.; Keppler, B.K.; et al. Novel metal(II)-arene 2-pyridinecarbothioamides: A rationale to orally active organometallic anticancer agents. Chem. Sci. 2013, 4, 1837-1846.

76. Alagesan, M.; Bhuvanesh, N.S.P.; Dharmaraj, N. An investigation on new ruthenium(II) hydrazone complexes as anticancer agents and their interaction with biomolecules. Dalton Trans. 2014, 43, 6087-6099.

77. Alagesan, M.; Sathyadevi, P.; Krishnamoorthy, P.; Bhuvanesh, N.S.P.; Dharmaraj, N. DMSO containing ruthenium(II) hydrazone complexes: In vitro evaluation of biomolecular interaction and anticancer activity. Dalton Trans. 2014, 43, 15829-15840.

78. Hanif, M.; Nawaz, M.; Babak, M.; Iqbal, J.; Roller, A.; Keppler, B.; Hartinger, C.G. Ruthenium $^{\mathrm{II}}\left(\eta^{6}\right.$-arene) complexes of thiourea derivatives: Synthesis, characterization and urease inhibition. Molecules 2014, 19, 8080-8092. 
79. Liao, G.; Chen, X.; Wu, J.; Qian, C.; Wang, Y.; Ji, L.; Chao, H. Ruthenium(II) polypyridyl complexes as dual inhibitors of telomerase and topoisomerase. Dalton Trans. 2015, 44, $15145-15156$.

80. He, X.; Jin, L.; Tan, L. DNA-binding, topoisomerases I and II inhibition and in vitro cytotoxicity of ruthenium(II) polypyridyl complexes: $\left[\mathrm{Ru}(\mathrm{dppz})_{2} \mathrm{~L}\right]^{2+}\left(\mathrm{L}=\mathrm{dppz}-11-\mathrm{CO}_{2} \mathrm{Me}\right.$ and dppz). Spectrochim. Acta A 2015, 135, 101-109.

81. Murray, B.S.; Menin, L.; Scopelliti, R.; Dyson, P. Conformational control of anticancer activity: The application of arene-linked dinuclear ruthenium(II) organometallics. Chem. Sci. 2014, 5, 2536-2545.

82. Sadafi, F.-Z.; Massai, L.; Bartolommei, G.; Moncelli, M.R.; Messori, L.; Tadini-Buoninsegni, F. Anticancer ruthenium(III) complex KP1019 interferes with ATP-dependent $\mathrm{Ca}^{2+}$ translocation by sarco-endoplasmic reticulum $\mathrm{Ca}^{2+}$-ATPase (SERCA). ChemMedChem 2014, 9, 1660-1664.

83. He, L.; Huang, Y.; Zhu, H.; Pang, G.; Zheng, W.; Wong, Y.-S.; Chen, T. Cancer-targeted monodisperse mesoporous silica nanoparticles as carrier of ruthenium polypyridyl complexes to enhance theranostic effects. Adv. Funct. Mater. 2014, 24, 2754-2763.

84. Gueugnon, F.; Denis, I.; Pouliquen, D.; Collette, F.; Delatouche, R.; Héroguez, V.; Grégoire, M.; Bertrand, P.; Blanquart, C. Nanoparticles produced by ring-opening metathesis polymerization using norbornenyl-poly(ethylene oxide) as a ligand-free generic platform for highly selective in vivo tumor targeting. Biomacromolecules 2013, 14, 2396-2402.

85. Blunden, B.M.; Lu, H.; Stenzel, M.H. Enhanced delivery of the RAPTA-C macromolecular chemotherapeutic by conjugation to degradable polymeric micelles. Biomacromolecules 2013, $14,4177-4188$.

86. Adeniyi, A.A.; Ajibade, P.A. An insight into the anticancer activities of Ru(II)-based metallocompounds using docking methods. Molecules 2013, 18, 10829-10856.

87. Sinesio de Freitas, E.; Bento da Silva, P.; Chorilli, M.; Batista, A.A.; de Oliveira Lopes, E.; Martins da Silva, M.; Fujimura Leite, C.Q.; Pavan, F.R. Nanostructured lipid systems as a strategy to improve the in vitro cytotoxicity of ruthenium(II) compounds. Molecules 2014, 19, 5999-6008.

88. Wills, R.H.; Habtemariam, A.; Lopez-Clavijo, A.F.; Barrow, M.P.; Sadler, P.J.; O’Connor, P.B. Insights into the binding sites of organometallic ruthenium anticancer compounds on peptides using ultra-high resolution mass spectrometry. J. Am. Soc. Mass Spectrom. 2014, 25, 662-672.

89. Zhou, X.; Zhu, D.; Liao, Y.; Liu, W.; Liu, H.; Ma, Z.; Xing, D. Synthesis, labeling and bioanalytical applications of a tris(2,2'-bipyridyl)ruthenium(II)-based electrochemiluminescence probe. Nat. Protocols 2014, 9, 1146-1159.

90. Wragg, A.; Gill, M.R.; Turton, D.; Adams, H.; Roseveare, T.M.; Smythe, C.; Su, X.; Thomas, J.A. Tuning the cellular uptake properties of luminescent heterobimetallic iridium(III)-ruthenium(II) DNA imaging probes. Chem. Eur. J. 2014, 20, 14004-14011.

91. Harvey, P.D.; Tasan, S.; Gros, C.P.; Devillers, C.H.; Richard, P.; Le Gendre, P.; Bodio, E. Ruthenium and osmium complexes of phosphine-porphyrin derivatives as potential bimetallic theranostics: Photophysical studies. Organometallics 2015, 34, 1218-1227. 
92. Greenough, S.E.; Roberts, G.M.; Smith, N.A.; Horbury, M.D.; McKinlay, R.G.; Żurek, J.M.; Paterson, M.J.; Sadler, P.J.; Stavros, V.G. Ultrafast photo-induced ligand solvolysis of cis-[Ru(bipyridine)2(nicotinamide)2 $]^{2+}$ : Experimental and theoretical insight into its photoactivation mechanism. Phys. Chem. Chem. Phys. 2014, 16, 19141-19155.

93. Ayaz Ahmed, K.B.; Reshma, E.; Mariappan, M.; Anbazhagan, V. Spectroscopic investigation on the interaction of ruthenium complexes with tumor specific lectin, jacalin. Spectrochim. Acta A 2015, 137, 1292-1297.

94. Lin, Y.; Huang, Y.; Zheng, W.; Wu, K.; Luo, Q.; Zhao, Y.; Xiong, S.; Wang, F. Quantification of bindings of organometallic ruthenium complexes to GST $\pi$ by mass spectrometry. J. Inorg. Biochem. 2015, 146, 44-51.

95. Busto, N.; Martínez-Alonso, M.; Leal, J.M.; Rodríguez, A.M.; Domínguez, F.; Acuña, M.I.; Espino, G.; García, B. Monomer-dimer divergent behavior toward DNA in a half-sandwich ruthenium(II) aqua complex. Antiproliferative biphasic activity. Organometallics 2015, 34, 319-327.

96. Zhang, S.; Ding, Y.; Wei, H. Ruthenium polypyridine complexes combined with oligonucleotides for bioanalysis: A review. Molecules 2014, 19, 11933-11987.

97. Adeniyi, A.A.; Ajibade, P.A. Comparing the suitability of autodock, gold and glide for the docking and predicting the possible targets of $\mathrm{Ru}(\mathrm{II})$-based complexes as anticancer agents. Molecules 2013, 18, 3760-3778.

98. Zhang, Z.; Wu, Q.; Wu, X.-H.; Sun, F.-Y.; Chen, L.-M.; Chen, J.-C.; Yang, S.-L.; Mei, W.-J. Ruthenium(II) complexes as apoptosis inducers by stabilizing $c-m y c$ G-quadruplex DNA. Eur. J. Med. Chem. 2014, 80, 316-324.

99. Wu, K.; Liu, S.; Luo, Q.; Hu, W.; Li, X.; Wang, F.; Zheng, R.; Cui, J.; Sadler, P.J.; Xiang, J.; et al. Thymines in single-stranded oligonucleotides and G-quadruplex DNA are competitive with guanines for binding to an organoruthenium anticancer complex. Inorg. Chem. 2013, 52, 11332-11342.

100. Wu, K.; Hu, W.; Luo, Q.; Li, X.; Xiong, S.; Sadler, P.J.; Wang, F. Competitive binding sites of a ruthenium arene anticancer complex on oligonucleotides studied by mass spectrometry: Ladder-sequencing versus top-down. J. Am. Soc. Mass Spectrom. 2013, 24, 410-420.

101. Menéndez-Pedregal, E.; Díez, J.; Manteca, A.; Sánchez, J.; Bento, A.C.; García-Navas, R. Antitumor activity of new enantiopure pybox-ruthenium complexes. Dalton Trans. 2013, 42, 13955-13967.

102. Mu, C.; Walsby, C.J. Ruthenium anticancer compounds with biologically-derived ligands. In Ligand Design in Medicinal Inorganic Chemistry; Storr, T., Ed.; John Wiley \& Sons, Ltd.: Chichester, UK, 2014; Chapter 15.

103. Paul, L.E.H.; Furrer, J.; Therrien, B. Reactions of a cytotoxic hexanuclear arene ruthenium assembly with biological ligands. J. Organomet. Chem. 2013, 734, 45-52.

104. Rathgeb, A.; Böhm, A.; Novak, M.S.; Gavriluta, A.; Dömötör, O.; Tommasino, J.B.; Enyedy, E.A.; Shova, S.; Meier S.; Jakupec, M.A.; et al. Ruthenium-nitrosyl complexes with glycine, L-alanine, L-valine, L-proline, D-proline, L-serine, L-threonine, and L-tyrosine: Synthesis, X-ray diffraction structures, spectroscopic and electrochemical properties, and antiproliferative activity. Inorg. Chem. 2014, 53, 2718-2729. 
105. Aman, F.; Hanif, M.; Siddiqui, W.A.; Ashraf, A.; Filak, L.K.; Reynisson, J.; Söhnel, T.; Jamieson, S.M.F.; Hartinger, C.G. Anticancer ruthenium $\left(\eta^{6}-p\right.$-cymene) complexes of nonsteroidal anti-inflammatory drug derivatives. Organometallics 2014, 33, 5546-5553.

106. Kandioller, W.; Balsano, E.; Meier, S.M.; Jungwirth, U.; Göschl, S.; Roller, A.; Jakupec, A.; Berger, W.; Keppler, B.K.; Hartinger, C.G. Organometallic anticancer complexes of lapachol: Metal centre-dependent formation of reactive oxygen species and correlation with cytotoxicity. Chem. Commun. 2013, 49, 3348-3350.

107. Pettinari, R.; Marchetti, F.; Condello, F.; Pettinari, C.; Lupidi, G.; Scopelliti, R.; Mukhopadhyay, S.; Riedel, T.; Dyson, P.J. Ruthenium(II)-arene RAPTA type complexes containing curcumin and bisdemethoxycurcumin display potent and selective anticancer activity. Organometallics 2014, 33, 3709-3715.

108. Collins, I.; Jones, A.M. Diversity-oriented synthetic strategies applied to cancer chemical biology and drug discovery. Molecules 2014, 19, 17221-17255.

109. Devi, C.S.; Nagababu, P.; Natarajan, S.; Deepika, N.; Venkat Reddy, P.; Veerababu, N.; Singh, S.S.; Satyanarayana, S. Cellular uptake, cytotoxicity, apoptosis and DNA-binding investigations of Ru(II) complexes. Eur. J. Med. Chem. 2014, 72, 160-169.

110. Mari, C.; Pierroz, V.; Ferrari, S.; Gasser, G. Combination of Ru(II) complexes and light: New frontiers in cancer therapy. Chem. Sci. 2015, 6, 2660-2686.

111. Joshi, T.; Gasser, G. Towards tris(diimine)-ruthenium(II) and bis(quinoline)-Re(I)(CO) 3 complexes as photoactivated anticancer drug candidates. Synlett 2015, 26, 275-284.

112. Yin, H.; Stephenson, M.; Gibson, J.; Sampson, E.; Shi, G.; Sainuddin, T.; Monro, S.; McFarland, S.A. In vitro multiwavelength PDT with ${ }^{3}$ IL states: Teaching old molecules new tricks. Inorg. Chem. 2014, 53, 4548-4559.

113. Saraf, S.L.; Fish, T.J.; Benninghoff, A.D.; Buelt, A.A.; Smith, R.C.; Berreau, L.M. Photochemical reactivity of $\mathrm{Ru}(\mathrm{II})\left(\eta^{6}-p\right.$-cymene) flavonolato compounds. Organometallics 2014, 33, 6341-6351.

114. Dickerson, M.; Sun, Y.; Howerton, B.; Glazer, E.C. Modifying charge and hydrophilicity of simple $\mathrm{Ru}(\mathrm{II})$ polypyridyl complexes radically alters biological activities: Old complexes, surprising new tricks. Inorg. Chem. 2014, 53, 10370-10377.

115. Askes, S.H.C.; Bahreman, A.; Bonnet, S. Activation of a photodissociative ruthenium complex by triplet-triplet annihilation upconversion in liposomes. Angew. Chem. Int. Ed. 2014, 53, 1029-1033.

116. Liu, J.; Chen, Y.; Li, G.; Zhang, P.; Jin, C.; Zeng, L.; Ji, L.; Chao, H. Ruthenium(II) polypyridyl complexes as mitochondria-targeted two-photon photodynamic anticancer agents. Biomaterials 2015, 56, 140-153.

117. Albani, B.A.; Peña, B.; Leed, N.A.; de Paula, N.A.B.G.; Pavani, C.; Baptista, M.S.; Dunbar, K.R.; Turro, C. Marked improvement in photoinduced cell death by a new trisheteroleptic complex with dual action: Singlet oxygen sensitization and ligand dissociation. J. Am. Chem. Soc. 2014, 136, 17095-17101.

118. Sgambellone, M.A.; David, A.; Garner, R.N.; Dunbar, K.R.; Turro, C. Cellular toxicity induced by the photorelease of a caged bioactive molecule: Design of a potential dual-action $\mathrm{Ru}(\mathrm{II})$ complex. J. Am. Chem. Soc. 2013, 135, 11274-11282. 
119. Sears, R.B.; Joyce, L.E.; Ojaimi, M.; Gallucci, J.C.; Thummel, R.P.; Turro, C. Photoinduced ligand exchange and DNA binding of cis-[Ru(phpy)(phen) $\left.\left(\mathrm{CH}_{3} \mathrm{CN}\right)_{2}\right]^{+}$with long wavelength visible light. J. Inorg. Biochem. 2013, 121, 77-87.

120. Frasconi, M.; Liu, Z.; Lei, J.; Wu, Y.; Strekalova, E.; Malin, D.; Ambrogio, M.W.; Chen, X.; Botros, Y.Y.; Cryns, V.L.; et al. Photoexpulsion of surface-grafted ruthenium complexes and subsequent release of cytotoxic cargos to cancer cells from mesoporous silica nanoparticles. J. Am. Chem. Soc. 2013, 135, 11603-11613.

121. Singh, S.K.; Pandey, D.S. Multifaceted half-sandwich arene-ruthenium complexes: Interactions with biomolecules, photoactivation, and multinuclearity approach. RSC Adv. 2014, 4, 1819-1840.

122. Chen, Y.; Lei, W.; Jiang, G.; Hou, Y.; Li, C.; Zhang, B.; Zhou, Q.; Wang, X. Fusion of photodynamic therapy and photoactivated chemotherapy: A novel Ru(II) arene complex with dual activities of photobinding and photocleavage toward DNA. Dalton Trans. 2014, 43, 15375-15384.

123. Nakabayashi, Y.; Nakamura, H.; Kubota, Y.; Morimoto, M.; Kawasaki, T.; Nakai, M.; Yamauchi, O. DNA interaction with dipolar ruthenium(II) ammine complexes containing 4,4'-bipyridinium as photochemotherapeutic agents. Inorg. Chim. Acta 2014, 423, 109-114.

124. Frei, A.; Rubbiani, R.; Tubafard, S.; Blacque, O.; Anstaett, P.; Felgenträger, A.; Maisch, T.; Spiccia, L.; Gasser, G. Synthesis, characterization, and biological evaluation of new $\mathrm{Ru}(\mathrm{II})$ polypyridyl photosensitizers for photodynamic therapy. J. Med. Chem. 2014, 57, 7280-7292.

125. Mari, C.; Pierroz, V.; Rubbiani, R.; Patra, M.; Hess, J.; Spingler, B.; Oehninger, L.; Schur, J.; Ott, I.; Salassa, L.; et al. DNA intercalating Ru(II) polypyridyl complexes as effective photosensitizers in photodynamic therapy. Chem. Eur. J. 2014, 20, 14421-14436.

126. Soldevila-Barreda, J.J.; Sadler, P.J. Approaches to the design of catalytic metallodrugs. Curr. Opin. Chem. Biol. 2015, 25, 172-183.

127. Soldevila-Barreda, J.J.; Romero-Canelón, I.; Habtemariam, A.; Sadler, P.J. Transfer hydrogenation catalysis in cells as a new approach to anticancer drug design. Nat. Commun. 2015, 6, 6582, doi:10.1038/ncomms4462.

128. Roveda, A.C., Jr.; Ruiz Papa, T.B.; Castellano, E.E.; Franco, D.W. PAMAM dendrimers functionalized with ruthenium nitrosyl as nitric oxide carriers. Inorg. Chim. Acta 2014, 409, 147-155.

129. Fry, N.L.; Mascharak, P.K. Photoactive ruthenium nitrosyls as NO donors: How to sensitize them toward visible light. Acc. Chem. Res. 2011, 44, 289-298.

130. De Lima, R.G.; Silva, B.R.; da Silva, R.S.; Bendhack, L.M. Ruthenium complexes as NO donors for vascular relaxation induction. Molecules 2014, 19, 9628-9654.

131. Tahghighi, A. Importance of metal complexes for development of potential leishmanicidal agents. J. Organomet. Chem. 2014, 770, 51-60.

132. Sarniguet, C.; Toloza, J.; Cipriani, M.; Lapier, M.; Vieites, M.; Toledano-Magaña, Y.; García-Ramos, J.C.; Ruiz-Azuara, L.; Moreno, V.; Maya, J.D.; et al. Water-soluble ruthenium complexes bearing activity against protozoan parasites. Biol. Trace Elem. Res. 2014, 159, 379-392.

133. Maurya, R.C.; Mir, J.M. Medicinal industrial \& environmental relevance of metal nitrosyl complexes: A review. Int. J. Sci. Eng. Res. 2014, 5, 305-320.

134. El-Gamel, N.E.A.; Fekry, A.M. Antimicrobial ruthenium complex coating on the surface of titanium alloy. High efficiency anticorrosion protection of ruthenium complex. Bioelectrochemistry 2015, 104, 35-43. 
135. Dixneuf, P.H., Bruneau, C. Ruthenium in Catalysis; Springer: Berlin, Germany, 2014.

136. Baraut, J.; Massard, A.; Chotard, F.; Bodio, E.; Picquet, M.; Richard, P.; Borguet, Y.; Nicks, F.; Demonceau, A.; Le Gendre, P. Assessment of catalysis by arene-ruthenium complexes containing phosphane or NHC groups bearing pendant conjugated diene systems. Eur. J. Inorg. Chem. 2015, 2671-2682.

137. Okamura, M.; Masaoka, S. Design of mononuclear ruthenium catalysts for low-overpotential water oxidation. Chem. Asian J. 2015, 10, 306-315.

138. Di Giovanni, C.; Vaquer, L.; Sala, X.; Benet-Buchholz, J.; Llobet, A. New dinuclear ruthenium complexes: Structure and oxidative catalysis. Inorg. Chem. 2013, 52, 4335-4345.

139. Laine, T.M.; Kärkäs, M.D.; Liao, R.-Z.; Åkermark, T.; Lee, B.-L.; Karlsson, E.A.; Siegbahn, P.E.M.; Åkermark, B. Efficient photochemical water oxidation by a dinuclear molecular ruthenium complex. Chem. Commun. 2015, 51, 1862-1865.

140. Artz, J.; Mallmann, S.; Palkovits, R. Selective aerobic oxidation of HMF to 2,5-diformylfuran on covalent triazine frameworks-supported Ru catalysts. ChemSusChem 2015, 8, 672-679.

141. Jahroni, B.T.; Kharat, A.N.; Amini, M.M.; Khavasi, H. Ruthenium diphosphine complexes as an efficient hydroamination catalyst. Appl. Petrochem. Res. 2015, 5, 105-112.

142. Bantreil, X.; Cazin, C.S.J. Phosphite ligands in Ru-based olefin metathesis catalysts. Monatsh. Chem. 2015, 145, 1043-1052.

143. Varela, J.A.; Gonzales-Rodriguez, C.; Saa, C. Catalytic transformations of alkynes via ruthenium vinylidene and allenylidene intermediates. In Ruthenium in Catalysis; Dixneuf, P.H., Bruneau, C., Eds.; Springer: Berlin, Germany, 2014; Chapter 7, pp. 237-287

144. Dixneuf, P.H.; Bruneau, C. Ruthenium indenylidene catalysts for alkene metathesis. In Handbook of Metathesis: Catalyst Development and Mechanism, 2nd ed.; Grubbs, R.H., Wenzel, A.G., Eds.; Wiley-VCH: Weinheim, Germany, 2015; Volume 3, Chapter 14, pp. 389-416.

145. Urbina-Blanco, C.A.; Guidone, S.; Nolan, S.P.; Cazin, C.S.J. Ruthenium-indenylidene and other alkylidene containing olefin metathesis catalysts. In Olefin Metathesis: Theory and Practice; Grela, K., Ed.; John Wiley \& Sons: Hoboken, NJ, USA, 2014; Chapter 15, pp. 417-436.

146. Ding, F.; Sun, Y.; Verpoort, F.; Dragutan, V.; Dragutan, I. Catalytic activity and selectivity of a range of ruthenium complexes tested in the styrene/EDA reaction system. J. Mol. Catal. A: Chem. 2014, 386, 86-94.

147. Marx, V.M.; Rosebrugh, L.E.; Herbert, M.B.; Grubbs, R.H. Cyclometalated ruthenium alkylidene complexes: A powerful family of Z-selective olefin metathesis catalysts. In Ruthenium in Catalysis; Dixneuf, P.H., Bruneau, C., Eds.; Springer: Berlin, Germany, 2014; Chapter 1, pp. 1-17.

148. Nolan, S.P. N-Heterocyclic Carbenes: Effective Tools for Organometallic Synthesis, 1st ed.; Wiley-VCH: Weinheim, Germany, 2014; p. 568.

149. Levin, E.; Ivry, E.; Diesendruck, C.E.; Lemcoff, N.G. Water in $N$-heterocyclic carbene-assisted catalysis. Chem. Rev. 2015, 115, 4607-4692.

150. Schwartsburd, L.; Whittlesey, M.K. Ruthenium $N$-heterocyclic carbene complexes for the catalysis of nonmetathesis organic transformations. In N-Heterocyclic Carbenes: Effective Tools for Organometallic Synthesis, 1st ed.; Nolan, S.P., Ed.; Wiley-VCH: Weinheim, Germany, 2014; Chapter 12, pp. 341-369. 
151. Méret, M.; Maj, A.M.; Demonceau, A.; Delaude, L. Ruthenium-arene catalysts bearing $N$-heterocyclic carbene ligands for olefin cyclopropanation and metathesis. Monatsh. Chem. 2015, 146, 1099-1105.

152. Yang, D.; Tang, Y.; Song, H.; Wang, B. $O$-Aryloxide- $N$-heterocyclic carbenes: Efficient synthesis of the proligands and their $p$-cymene ruthenium complexes. Organometallics 2015, 34, 2012-2017.

153. Hitzel, S.; Färber, C.; Bruhn, C.; Siemeling, U. Reactions of $\left[\mathrm{RuCl}_{2}\left(\mathrm{PPh}_{3}\right)_{3}\right]$ with nitron and with the "Enders carbene": Access to ruthenium(III) NHC complexes. Organometallics 2014, 33, $425-428$.

154. Yaşar, S.; Çekirdek, S.; Özdemir, I. Synthesis, characterization, and transfer hydrogenation of $\mathrm{Ru}(\mathrm{II})-\mathrm{N}$-heterocyclic carbene complexes. J. Coord. Chem. 2014, 67, 1236-1248.

155. Malineni, J.; Keul, H.; Möller, M. An efficient $N$-heterocyclic carbene-ruthenium complex: Application towards the synthesis of polyesters and polyamides. Macromol. Rapid Commun. 2015, 36, 547-552.

156. Marx, V.M.; Sullivan, A.H.; Melaimi, M.; Virgil, S.C.; Keitz, B.K.; Weinberger, D.S.; Bertrand, G.; Grubbs, R.H. Cyclic alkyl amino carbene (CAAC) ruthenium complexes as remarkably active catalysts for ethenolysis. Angew. Chem. Int. Ed. 2015, 54, 1919-1923.

157. Dragutan, V.; Dragutan, I.; Delaude, L.; Demonceau, A. Exploring new achievements in olefin metathesis catalysts. Part 1 . Highlights on $N$-heterocyclic carbene ruthenium complexes. Chem. Today 2009, 27, S9-S12.

158. Troian-Gautier, L.; Moucheron, C. Ruthenium ${ }^{\mathrm{II}}$ complexes bearing fused polycyclic ligands: From fundamental aspects to potential applications. Molecules 2014, 19, 5028-5087.

159. Mariconda, A.; Longo, P.; Agovino, A.; Guadagno, L.; Sorrentino, A.; Raimondo, M. Synthesis of ruthenium catalysts functionalized graphene oxide for self-healing applications. Polymer 2015, 69, 330-342.

160. Balaraman, E.; Milstein, D. Hydrogenation of polar bonds catalysed by ruthenium-pincer complexes. In Ruthenium in Catalysis; Dixneuf, P.H., Bruneau, C., Eds.; Springer: Berlin, Germany, 2014; Chapter 2, pp. 19-43.

161. Suresh, P.; Munisamy, V.; Prabusankar, G. Synthesis, characterization and applications of vinyl functionalized $N$-heterocyclic carbene supported ruthenium(II) derivatives. Indian J. Chem. 2015, 54A, 588-595.

162. Chen, T.; Li, H.; Qu, S.; Zheng, B.; He, L.; Lai, Z.; Wang, Z.-X.; Huang, K.-W. Hydrogenation of esters catalyzed by ruthenium $\mathrm{PN}^{3}$-pincer complexes containing an aminophosphine arm. Organometallics 2014, 33, 4152-4155.

163. Huff, C.A.; Sanford, M.S. Catalytic $\mathrm{CO}_{2}$ hydrogenation to formate by a ruthenium pincer complex. ACS Catal. 2013, 3, 2412-2416.

164. Rezayee, N.M.; Huff, C.A.; Sanford, M.S. Tandem amine and ruthenium-catalyzed hydrogenation of $\mathrm{CO}_{2}$ to methanol. J. Am. Chem. Soc. 2015, 137, 1028-1031.

165. Wesselbaum, S.; Moha, V.; Meuresch, M.; Brosinski, S.; Thenert, K.M.; Kothe, J.; vom Stein, T.; Englert, U.; Hölscher, M.; Klankermayer, J.; et al. Hydrogenation of carbon dioxide to methanol using a homogeneous ruthenium-Triphos catalyst: From mechanistic investigations to multiphase catalysis. Chem. Sci. 2015, 6, 693-704. 
166. Aho, A.; Roggan, S.; Eränen, K.; Salmi, T.; Murzin, D.Y. Continuous hydrogenation of glucose with ruthenium on carbon nanotube catalysts. Catal. Sci. Technol. 2015, 5, 953-959.

167. Václavík, J.; Šot, P.; Pecháček, J.; Vilhanová, B.; Matuška, O.; Kuzma, M.; Kačer, P. Experimental and theoretical perspectives of the Noyori-Ikariya asymmetric transfer hydrogenation of imines. Molecules 2014, 19, 6987-7007.

168. Karabuga, S.; Bars, S.; Karakaya, I.; Gumus, S. Efficient transfer hydrogenation reactions with quinazoline-based ruthenium complexes. Tetrahedron Lett. 2015, 56, 101-104.

169. Bhosale, S.S.; Singh, K.S. Ruthenium(II)-catalyzed transfer hydrogenation of aromatic and heteroaromatic aldehydes in air. Synth. Commun. 2015, 45, 1411-1420.

170. Zimbron, J.M.; Dauphinais, M.; Charette, A.B. Noyori-Ikariya catalyst supported on tetra-arylphosphonium salt for asymmetric transfer hydrogenation in water. Green Chem. 2015, 17, 3255-3259.

171. Zoabi, A.; Omar, S.; Abu-Reziq, R. Chiral ruthenium catalyst immobilized within magnetically retrievable mesoporous silica microcapsules for aqueous asymmetric transfer hydrogenations. Eur. J. Inorg. Chem. 2015, 2015, 2101-2109.

172. Sarkar, S.M.; Yusoff, M.M.; Rahman, M.L. Asymmetric transfer hydrogenation catalyzed by mesoporous MCM-41-supported chiral Ru-complex. J. Chin. Chem. Soc. 2015, 62, 177-181.

173. Hudson, R.; Chazelle, V.; Bateman, M.; Roy, R.; Li, C.-J.; Moores, A. Sustainable synthesis of magnetic ruthenium-coated iron nanoparticles and application in the catalytic transfer hydrogenation of ketones. ACS Sustain. Chem. Eng. 2015, 3, 814-820.

174. Wang, Z.-M.; Sang, X.-L.; Che, C.-M.; Chen, J. Ruthenium(IV) porphyrin catalyzed highly selective oxidation of internal alkenes into ketones with $\mathrm{Cl}_{2}$ pyNO as terminal oxidant. Tetrahedron Lett. 2014, 55, 1736-1739.

175. Bruneau, C. $\mathrm{sp}^{3} \mathrm{C}-\mathrm{H}$ bond functionalization with ruthenium catalysts. In Ruthenium in Catalysis; Dixneuf, P.H., Bruneau, C., Eds.; Springer: Berlin, Germany, 2014; Chapter 6, pp.195-236.

176. Li, B.; Dixneuf, P.H. Ruthenium(II)-catalysed $\mathrm{sp}^{2} \mathrm{C}-\mathrm{H}$ bond functionalization by $\mathrm{C}-\mathrm{C}$ bond formation. In Ruthenium in Catalysis; Dixneuf, P.H., Bruneau, C., Eds.; Springer: Berlin, Germany, 2014; Chapter 5, pp. 119-193.

177. Kulago, A.A.; van Steijvoort, B.F.; Mitchell, E.A.; Meerpoel, L.; Maes, B.U.W. Directed ruthenium-catalyzed $\mathrm{C}\left(\mathrm{sp}^{3}\right)-\mathrm{H} \quad \alpha$-alkylation of cyclic amines using dioxolane-protected alkenones. Adv. Synth. Catal. 2014, 356, 1610-1618.

178. Kobayashi, Y.; Kashiwa, M.; Sonoda, M.; Kirihata, M.; Tanimori, S. Regioselective monoarylation of 2-phenylbenzimidazole via ruthenium-catalyzed $\mathrm{C}-\mathrm{H}$ bond functionalization. Synthesis 2014, 46, 3185-3190.

179. Gonell, S.; Peris, E. Pyrene-based mono- and di- $N$-heterocyclic carbene ligand complexes of ruthenium for the preparation of mixed arylated/alkylated arylpyridines. ACS Catal. 2014, 4, 2811-2817.

180. Schmidt, B.; Hauke, S.; Mühlenberg, N. Imino glycals via ruthenium-catalyzed RCM and isomerization. Synthesis 2014, 46, 1648-1658.

181. Higman, C.S.; Plais, L.; Fogg, D.E. Isomerization during olefin metathesis: Assessment of potential culprits. ChemCatChem 2013, 5, 3548-3551. 
182. Suárez, F.J.; Vidal, C.; García-Álvarez, J. Redox isomerization of allylic alcohols to carbonyl compounds catalyzed by ruthenium(IV) complexes containing $N$-heterocyclic ligands in ionic liquids. Curr. Green Chem. 2014, 1, 121-127.

183. Takagi, R.; Abe, M. [3 + 2] Cycloaddition of $\alpha, \beta$-unsaturated metal-carbene complexes. In Methods and Applications of Cycloaddition Reactions Organic Syntheses; Nishiwaki, N., Ed.; John Wiley \& Sons: New York, NY, USA, 2014; Chapter 5.

184. Derien, S. C-C Bond formation on activation of alkynes and alkenes with $\left(\mathrm{C}_{5} \mathrm{R}_{5}\right) \mathrm{Ru}$ catalysts. In Ruthenium in Catalysis; Dixneuf, P.H., Bruneau, C., Eds.; Springer: Berlin, Germany, 2014; Chapter 8, pp. 289-318.

185. Grubbs, R.H.; Wenzel, A.G.; O’Leary, D.J.; Khosravi, E. Handbook of Metathesis, 2nd ed.; Wiley-VCH: Weinheim, Germany, 2015; Volume 3, p. 1608.

186. Crochet, P.; Cadierno, V. Ruthenium-catalyzed amide-bond formation. In Ruthenium in Catalysis; Dixneuf, P.H., Bruneau, C., Eds.; Springer: Berlin, Germany, 2014; Chapter 4, pp. 81-118.

187. Konigs, C.D.F.; Muller, M.F.; Aiguabella, N.; Klare, H.F.T.; Oestreich, M. Catalytic dehydrogenative $\mathrm{Si}-\mathrm{N}$ coupling of pyrroles, indoles, carbazoles as well as anilines with hydrosilanes without added base. Chem. Commun. 2013, 49, 1506-1508.

188. Långvik, O.; Mavrynsky, D.; Leino, R. Selective ruthenium-catalyzed epimerization of chiral sec-alcohols. Catal. Today 2015, 241, 255-259.

189. Curvey, N.; Widaman, A.K.; Rath, N.P.; Bauer, E.B. Ruthenium complexes of the general formula $\left[\mathrm{RuCl}_{2}\left(\mathrm{PHOX}_{2}\right]\right.$ and their catalytic activity in the Mukaiyama aldol reaction. Tetrahedron Lett. 2014, 55, 3033-3037.

190. Yeung, C.-F.; Chung, L.-H.; Lo, H.-S.; Chiu, C.-H.; Cai, J.; Wong, C.-Y. Isolation of rutheniumindoline and -indole zwitterion complexes: Insight into the metal-induced cyclization of aniline-tethered alkynes and strategy to lower the activation barrier of metal-vinylidene formation. Organometallics 2015, 34, 1963-1968.

191. Diaba, F.; Martínez-Laporta, A.; Bonjoch, J. Atom transfer radical cyclization of trichloroacetamides to electron-rich acceptors using Grubbs' catalysts: Synthesis of the tricyclic framework of FR901483. J. Org. Chem. 2014, 79, 9365-9372.

192. Borguet, Y.; Sauvage, X.; Zaragoza, G.; Demonceau, A.; Delaude, L. Tandem catalysis of ring-closing metathesis/atom transfer radical reactions with homobimetallic ruthenium-arene complexes. Beilstein J. Org. Chem. 2010, 6, 1167-1173.

193. Friedberger, T.; Ziller, J.W.; Guan, Z. Ruthenium(IV) complexes for ethylene insertion polymerization. Organometallics 2014, 33, 1913-1916.

194. Kothandaraman, J.; Czaun, M.; Goeppert, A.; Haiges, R.; Jones, J.-P.; May, R.B.; Surya Prakash, G.K.; Olah, G.A. Amine-free reversible hydrogen storage in formate salts catalyzed by ruthenium pincer complex without pH control or solvent change. ChemSusChem 2015, 8, 1442-1451.

195. Milstein, D. Challenging metal-based transformations. From single-bond activation to catalysis and metallaquinonoids. Pure Appl. Chem. 2003, 75, 445-460.

196. Wagner, D.; Bräse, S. Ruthenium-catalyzed C-H activation of thioxanthones. Beilstein J. Org. Chem. 2015, 11, 431-436. 
197. Alsabeh, P.G.; Mellmann, D.; Junge, H.; Beller, M. Ruthenium-catalyzed hydrogen generation from alcohols and formic acid, including Ru-pincer type complexes. In Ruthenium in Catalysis; Dixneuf, P.H., Bruneau, C., Eds.; Springer: Berlin, Germany, 2014; Chapter 3, pp. 45-79.

198. Chen, Q.-A.; Cruz, F.A.; Dong, V.M. Alkyne hydroacylation: Switching regioselectivity by tandem ruthenium catalysis. J. Am. Chem. Soc. 2015, 137, 3157-3160.

199. Frost, J.R.; Huber, S.M.; Breitenlechner, S.; Bannwarth, C.; Bach, T. Enantiotopos-selektive $\mathrm{CH}-$ Oxygenierung mit einem supramolekularen Ruthenium-Katalysator. Angew. Chem. 2015, 127, 701-705.

200. Di Giovanni, C.; Poater, A.; Benet-Buchholz, J.; Cavallo, L.; Solà, M.; Llobet, A. Dinuclear Ru-aqua complexes for selective epoxidation catalysis based on supramolecular substrate orientation effects. Chem. Eur. J. 2014, 20, 3898-3902.

201. Duan, L.; Wang, L.; Li, F.; Li, F.; Sun, L. Highly efficient bioinspired molecular Ru water oxidation catalysts with negatively charged backbone ligands. Acc. Chem. Res. 2015, 48, 2084-2096.

202. Kaufhold, S.; Petermann, L.; Staehle, R.; Rau, S. Transition metal complexes with $N$-heterocyclic carbene ligands: From organometallic hydrogenation reactions toward water splitting. Coord. Chem. Rev. 2015, 304-305, 73-87.

203. Llobet, A. Molecular Water Oxidation Catalysis: A Key Topic for New Sustainable Energy Conversion Schemes; John Wiley \& Sons, Ltd.: Chichester, UK, 2014.

204. Wang, L.; Duan, L.; Wang, Y.; Ahlquist, M.S.G.; Sun, L. Highly efficient and robust molecular water oxidation catalysts based on ruthenium complexes. Chem. Commun. 2014, 50, 12947-12950.

205. Staehle, R.; Tong, L.; Wang, L.; Duan, L.; Fischer, A.; Ahlquist, M.S.G.; Sun, L.; Rau, S. Water oxidation catalyzed by mononuclear ruthenium complexes with a 2,2'-bipyridine-6,6'-dicarboxylate (bda) ligand: How ligand environment influences the catalytic behavior. Inorg. Chem. 2014, 53, 1307-1319.

206. Mulyana, Y.; Keene, F.R.; Spiccia, L. Cooperative effects in homogenous water oxidation catalysis by mononuclear ruthenium complexes. Dalton Trans. 2014, 43, 6819-6827.

207. Zeng, Q.; Lewis, F.W.; Harwood, L.M.; Hartl, F. Role of ligands in catalytic water oxidation by mononuclear ruthenium complexes. Coord. Chem. Rev. 2015, 304-305, 88-101.

208. Sander, A.C.; Maji, S.; Francàs, L.; Böhnisch, T.; Dechert, S.; Llobet, A.; Meyer, F. Highly efficient binuclear ruthenium catalyst for water oxidation. ChemSusChem 2015, 8, 1697-1702.

209. Prokopchuk, D.E.; Tsui, B.T.H.; Lough, A.J.; Morris, R.H. Bond cleavage with water and alcohol using a phosphine-free ruthenium carbene NCN pincer complex. Chem. Eur. J. 2014, 20, 16960-16968.

210. Wang, Y.; Ahlquist, M.S.G. A computational study of the mechanism for water oxidation by (bpc)(bpy)Ru ${ }^{\mathrm{II}} \mathrm{OH}_{2}$. Dalton Trans. 2014, 43, 13776-13782.

211. Muckerman, J.T.; Kowalczyk, M.; Badiei, Y.M.; Polyansky, D.E.; Concepcion, J.J.; Zong, R.; Thummel, R.P.; Fujita, E. New water oxidation chemistry of a seven-coordinate ruthenium complex with a tetradentate polypyridyl ligand. Inorg. Chem. 2014, 53, 6904-6913.

212. Wang, L.; Duan, L.; Tong, L.; Sun, L. Visible light-driven water oxidation catalyzed by mononuclear ruthenium complexes. J. Catal. 2013, 306, 129-132. 
213. Manbeck, G.F.; Brewer, K.J. Photoinitiated electron collection in polyazine chromophores coupled to water reduction catalysts for solar $\mathrm{H}_{2}$ production. Coord. Chem. Rev. 2013, 257, $1660-1675$.

214. $\mathrm{Xu}, \mathrm{J}$;; Boyer, C. Visible light photocatalytic thiol-ene reaction: An elegant approach for fast polymer postfunctionalization and step-growth polymerization. Macromolecules 2015, 48, 520-529.

215. Man, W.-L.; Lam, W.W.Y.; Lau, T.-C. Reactivity of nitrido complexes of ruthenium(VI), osmium(VI), and manganese(V) bearing Schiff base and simple anionic ligands. Acc. Chem. Res. 2014, 47, 427-439.

216. Man, W.-L.; Xie, J.; Pan, Y.; Lam, W.W.Y.; Kwong, H.-K.; Ip, K.-W.; Yiu, S.-M.; Lau, K.-C.; Lau, T.-C. C-N Bond cleavage of anilines by a (Salen)ruthenium(VI) nitrido complex. J. Am. Chem. Soc. 2013, 135, 5533-5536.

217. Miyada, T.; Kwan, E.H.; Yamashita, M. Synthesis, structure, and bonding properties of ruthenium complexes possessing a boron-based PBP pincer ligand and their application for catalytic hydrogenation. Organometallics 2014, 33, 6760-6770.

218. Sun, C.; Liu, M.; Sun, H.; Hang, F.; Sun, N.; Chen, D. Theoretical mechanism for selective catalysis of ruthenium complex catalyzed hydroboration of terminal alkynes to $Z$-vinylboronates. Int. J. Quant. Chem. 2015, 115, 59-67.

219. Bose, S.K.; Roy, D.K.; Shankhari, P.; Yuvaraj, K.; Mondal, B.; Sikder, A.; Ghosh, S. Syntheses and characterization of new vinyl-borylene complexes by the hydroboration of alkynes with $\left[\left(\mu_{3}-\mathrm{BH}\right)(\mathrm{Cp} * \mathrm{RuCO})_{2}(\mu-\mathrm{CO}) \mathrm{Fe}(\mathrm{CO})_{3}\right]$. Chem. Eur. J. 2013, 19, 2337-2343.

220. Conifer, C.; Gunanathan, C.; Rinesch, T.; Hölscher, M.; Leitner, W. Solvent-free hydrosilylation of terminal alkynes by reaction with a nonclassical ruthenium hydride pincer complex. Eur. J. Inorg. Chem. 2015, 2015, 333-339.

221. Wang, J.; Huang, L.; Yang, X.; Wei, H. Mechanistic investigation into catalytic hydrosilylation with a high-valent ruthenium(VI)-nitrido complex: A DFT study. Organometallics 2015, 34, $212-220$.

222. Liang, T.; Nguyen, K.D.; Zhang, W.; Krische, M.J. Enantioselective ruthenium-catalyzed carbonyl allylation via alkyne-alcohol $\mathrm{C}-\mathrm{C}$ bond-forming transfer hydrogenation: Allene hydrometalation vs oxidative coupling. J. Am. Chem. Soc. 2015, 137, 3161-3164.

223. Zhang, L.; Han, Z.; Zhao, X.; Wang, Z.; Ding, K. Highly efficient ruthenium-catalyzed $\mathrm{N}$-formylation of amines with $\mathrm{H}_{2}$ and $\mathrm{CO}_{2}$. Angew. Chem. Int. Ed. 2015, 54, 6186-6189.

224. Kumar, P.; Gupta, R.K.; Pandey, D.S. Half-sandwich arene ruthenium complexes: Synthetic strategies and relevance in catalysis. Chem. Soc. Rev. 2014, 43, 707-733.

225. Warner, M.C.; Bäckvall, J.-E. Racemization of olefinic alcohols by a carbonyl(cyclopentadienyl) ruthenium complex: Inhibition by the carbon-carbon double bond. Eur. J. Org. Chem. 2015, 2015, 2388-2393.

226. Warner, M.C.; Bäckvall, J.-E. Mechanistic aspects on cyclopentadienylruthenium complexes in catalytic racemization of alcohols. Acc. Chem. Res. 2013, 46, 2545-2555.

227. Mavrynsky, D.; Murzin, D.Y.; Leino, R. Kinetic studies on sec-alcohol racemization with dicarbonylchloro(pentabenzylcyclopentadienyl)- and dicarbonylchloro(pentaphenylcyclopentadienyl) ruthenium catalysts. ChemCatChem 2013, 5, 2436-2445. 
228. Stewart, B.; Nyhlen, J.; Martín-Matute, B.; Bäckvall, J.-E.; Privalov, T. A computational study of the $\mathrm{CO}$ dissociation in cyclopentadienyl ruthenium complexes relevant to the racemization of alcohols. Dalton Trans. 2013, 42, 927-934.

229. Cao, H.; Cai, L.-H.; Wang, C.-X.; Zhu, X.-H.; Li, Z.-M.; Hou, X.-F. Ligand effect in racemization and dynamic kinetic resolution of alcohols: Mechanism on cymene ruthenium complexes. J. Organomet. Chem. 2015, 775, 60-66.

230. Fernández-Salas, J.A.; Manzini, S.; Nolan, S.P. A Cationic ruthenium complex for the dynamic kinetic resolution of secondary alcohols. Chem. Eur. J. 2014, 20, 13123-13135.

231. Grubbs, R.H.; Wenzel, A.G. Handbook of Metathesis. Catalyst Development and Mechanism, 2nd ed.; Wiley-VCH: Weinheim, Germany, 2015; Volume 1, p. 448.

232. Borguet, Y.; Zaragoza, G.; Demonceau, A.; Delaude, L. Ruthenium catalysts bearing a benzimidazolylidene ligand for the metathetical ring-closure of tetrasubstituted cycloolefins. Dalton Trans. 2015, 44, 9744-9755.

233. Pump, E.; Poater, A.; Zirngast, M.; Torvisco, A.; Fischer, R.; Cavallo, L.; Slugove, C. Impact of electronic modification of the chelating benzylidene ligand in cis-dichloro-configured second-generation olefin metathesis catalysts on their activity. Organometallics 2014, 33, 2806-2813.

234. Kozłowska, A.; Dranka, M.; Zachara, J.; Pump, E.; Slugovc, C.; Skowerski, K.; Grela, K. Chelating ruthenium phenolate complexes-Synthesis, general catalytic activity and applications in olefin metathesis polymerisation. Chem. Eur. J. 2014, 43, 14120-14125.

235. Varnado, C.D., Jr.; Rosen, E.L.; Collins, M.S.; Lynch, V.M.; Bielawski, C.W. Synthesis and study of olefin metathesis catalysts supported by redox-switchable diaminocarbene[3]ferrocenophanes. Dalton Trans. 2013, 42, 13251-13264.

236. Delaude, L.; Demonceau, A.; Dragutan, I.; Dragutan, V. Recent advances in ruthenium catalysts for alkene metathesis. In Green Metathesis Chemistry: Great Challenges in Synthesis, Catalysis and Nanotechnology; Dragutan, V., Demonceau, A., Dragutan, I., Finkelshtein, E.S., Eds.; Springer: Dordrecht, The Netherlands, 2010; pp. 3-16.

237. Dragutan, I.; Dragutan, V.; Delaude, L.; Demonceau, A. N-Heterocyclic carbenes as highly efficient ancillary ligands in homogeneous and immobilized metathesis ruthenium catalytic systems. Arkivoc 2005, 206-253, doi:10.3998/ark.5550190.0006.a18.

238. Dragutan, V.; Dragutan, I.; Balaban, A.T. Single-site ruthenium metathesis catalysts: Progress in their design and synthesis. Platinum Metals Rev. 2001, 45, 155-163.

239. Dragutan, V.; Dragutan, I.; Balaban, A.T. Metathesis catalysed by platinum group metals-A new strategy for synthesis of organic compounds and polymers. Part I: Types of catalysts, metathesis activity and selectivity. Platinum Metals Rev. 2000, 44, 58-66.

240. Deraedt, C.; d'Halluin, M.; Astruc, D. The metathesis reactions: Recent trends and new challenges. Eur. J. Inorg. Chem. 2013, 2013, 4881-4908.

241. Grela, K. Olefin Metathesis: Theory and Practice; John Wiley \& Sons: Hoboken, NJ, USA, $2014 ;$ p. 608.

242. Grubbs, R.H.; O’Leary, D.J. Handbook of Metathesis: Applications in Organic Synthesis, 2nd ed.; Wiley-VCH: Weinheim, Germany, 2015; Volume 2, p. 744. 
243. Dragutan, V.; Demonceau, A.; Dragutan, I.; Finkelshtein, E.S. Green Metathesis Chemistry: Great Challenges in Synthesis, Catalysis and Nanotechnology; Springer: Dordrecht, The Netherlands, 2010; p. 425.

244. Imamoglu, Y.; Dragutan, V. Metathesis Chemistry: From Nanostructure Design to Synthesis of Advanced Materials; Springer: Dordrecht, The Netherlands, 2007; p. 504.

245. Dragutan, V.; Dragutan, I.; Balaban, A.T. Metathesis catalysed by platinum group metals-A new strategy for synthesis of organic compounds and polymers. Part III: Acyclic diene metathesis reactions and ring-opening metathesis polymerisations. Platinum Metals Rev. 2000, 44, 168-172.

246. Zukowska, K.; Grela, K. Cross metathesis. In Olefin Metathesis: Theory and Practice; Grela, K., Ed.; John Wiley \& Sons: Hoboken, NJ, USA, 2014; pp. 39-84.

247. O’Leary, D.J.; O’Neil, G.W. Cross-metathesis. In: Handbook of Metathesis, Applications in Organic Synthesis, 2nd ed.; Grubbs, R.H., O'Leary, D.J., Eds.; Wiley-VCH: Weinheim, Germany, 2015; Volume 2, Chapter 2, pp. 171-294.

248. Pietraszuk, C.; Pawluc, P.; Marciniec, B. Metathesis of silicon-containing olefins. In Handbook of Metathesis, Applications in Organic Synthesis, 2nd ed.; Grubbs, R.H., O’Leary, D.J., Eds.; Wiley-VCH: Weinheim, Germany, 2015; Volume 2, Chapter 9, pp. 583-631.

249. Méndez, L.; Mata, E.G. Solid-supported cross-metathesis and a formal alkane metathesis for the generation of biologically relevant molecules. ACS Comb. Sci. 2015, 17, 81-86.

250. Van Lierop, B.J.; Lummiss, J.A.M.; Fogg, D.E. Ring-closing metathesis. In Olefin Metathesis: Theory and Practice; Grela, K., Ed.; John Wiley \& Sons: Hoboken, NJ, USA, 2014; pp. 85-154.

251. Hanson, P.R.; Maitra, S.; Chegondi, R.; Markley, J.L. General ring-closing metathesis. In Handbook of Metathesis: Applications in Organic Synthesis, 2nd ed.; Grubbs, R.H., O’Leary, D.J., Eds.; Wiley-VCH: Weinheim, Germany, 2015; Volume 2, Chapter 1, pp. 1-170.

252. Monfette, S.; Fogg, D.E. Ring-closing metathesis: Synthesis of medium and large rings: Challenges and implications for sustainable synthesis. In Green Metathesis Chemistry: Great Challenges in Synthesis, Catalysis and Nanotechnology; Dragutan, V., Demonceau, A., Dragutan, I., Finkelshtein, E.S., Eds.; Springer: Dordrecht, The Netherlands, 2010; pp. 129-156.

253. Compain, P.; Hazelard, D. Synthesis of amine-containing heterocycles by metathesis reactions: Recent advances and opportunities. Top. Heterocycl. Chem. 2015, doi:10.1007/7081_2014_139.

254. Dragutan, V.; Dragutan, I.; Balaban, A.T. Metathesis catalysed by platinum group metals-A new strategy for synthesis of organic compounds and polymers. Part II: Applications of platinum metals metathesis catalysts in ring-closing reactions. Platinum Metals Rev. 2000, 44, 112-118.

255. Li, J.; Lee, D. Enyne metathesis. In Handbook of Metathesis Applications in Organic Synthesis, 2nd ed.; Grubbs, R.H., O’Leary, D.J., Eds.; Wiley-VCH: Weinheim, Germany, 2015, Volume 2, Chapter 5, pp. 381-444.

256. Astruc, D. Olefin metathesis reactions: From a historical account to recent trends. In Olefin Metathesis: Theory and Practice; Grela, K., Ed.; John Wiley \& Sons: Hoboken, NJ, USA, 2014; pp. 5-38.

257. Schmidt, B.; Krehl, S. Domino and other olefin metathesis reaction sequences. In Olefin Metathesis: Theory and Practice; Grela, K., Ed.; John Wiley \& Sons: Hoboken, NJ, USA, 2014; pp. 187-232. 
258. Nam, Y.H.; Snapper, M.L. Ruthenium-catalyzed tandem metathesis/non-metathesis processes. In Handbook of Metathesis Applications in Organic Synthesis, 2nd ed.; Grubbs, R.H., O'Leary, D.J., Eds.; Wiley-VCH: Weinheim, Germany, 2015; Volume 2, Chapter 4, pp. 311-380.

259. Bicchielli, D.; Borguet, Y.; Delaude, L.; Demonceau, A.; Dragutan, I.; Dragutan, V.; Jossifov, C.; Kalinova, R.; Nicks, F.; Sauvage, X. Recent applications of alkene metathesis in fine chemical synthesis. In Green Metathesis Chemistry: Great Challenges in Synthesis, Catalysis and Nanotechnology; Dragutan, V., Demonceau, A., Dragutan, I., Finkelshtein, E.S., Eds.; Springer: Dordrecht, The Netherlands, 2010; pp. 207-274.

260. Cossy, J.; Arseniyadis, S.; Meyer, C. Metathesis in Natural Product Synthesis: Strategies, Substrates and Catalysts; Wiley-VCH: Weinheim, Germany, 2010; p. 412.

261. Cossy, J. Applications in the synthesis of natural and biologically active molecules. In Olefin Metathesis: Theory and Practice; Grela, K., Ed.; John Wiley \& Sons: Hoboken, NJ, USA, 2014; pp. 287-310.

262. Rolfe, A.; Marcaurelle, L.A. Metathesis strategies in diversity-oriented synthesis. In Handbook of Metathesis Applications in Organic Synthesis, 2nd ed.; Grubbs, R.H., O’Leary, D.J., Eds.; Wiley-VCH: Weinheim, Germany, 2015; Volume 2, Chapter 11, pp. 659-697.

263. Vanderwal, C.D.; Walczak, M.A.; Danishefsky, S.J. Two vignettes: RCM in natural product total synthesis. In Handbook of Metathesis Applications in Organic Synthesis, 2nd ed.; Grubbs, R.H., O’Leary, D.J., Eds.; Wiley-VCH: Weinheim, Germany, 2015; Volume 2, Chapter 8, pp. 563-582.

264. Lin, Y.A.; Davis, B.G. Vignette: Extending the application of metathesis in chemical biologyThe development of site-selective peptide and protein modifications. In Handbook of Metathesis Applications in Organic Synthesis, 2nd ed.; Grubbs, R.H., O'Leary, D.J., Eds.; Wiley-VCH: Weinheim, Germany, 2015; Volume 2, Chapter 3, pp. 295-309.

265. Fandrick, K.R.; Savoie, J.; Yee, N.; J. Song, J.J.; Senanayake, C.H. Challenges and opportunities for scaling the ring-closing metathesis reaction in the pharmaceutical industry. In Olefin Metathesis: Theory and Practice; Grela, K., Ed.; John Wiley \& Sons: Hoboken, NJ, USA, 2014; pp. 349-366.

266. Farina, V.; Horváth, A. Ring-closing metathesis in the large-scale synthesis of pharmaceuticals. In Handbook of Metathesis Applications in Organic Synthesis, 2nd ed; Grubbs, R.H., O’Leary, D.J., Eds.; Wiley-VCH: Weinheim, Germany, 2015; Volume 2, Chapter 10, pp. 633-658.

267. Nickel, A.; Pederson, R.L. Commercial potential of olefin metathesis of renewable feedstocks. In Olefin Metathesis: Theory and Practice, Grela, K., Ed.; John Wiley \& Sons: Hoboken, NJ, USA, 2014; pp. 335-348.

268. Dassonneville, B.; Delaude, L.; Demonceau, A.; Dragutan, I.; Dragutan, V. Selected recent advances in the synthesis of bioactive compounds using olefin metathesis as a key step. Curr. Org. Chem. 2013, 17, 2609-2653.

269. Dragutan, I.; Dragutan, V.; Mitan, C.; Vosloo, H.C.M.; Delaude, L.; Demonceau, A. Metathesis access to monocyclic iminocyclitol-based therapeutic agents. Beilstein J. Org. Chem. 2011, 7, 699-716.

270. Dragutan, I.; Dragutan, V.; Demonceau, A.; Vosloo, H.C.M. Synthesis of castanospermine and epimers by metathesis routes. Curr. Org. Chem. 2013, 17, 2721-2739. 
271. Demonceau, A.; Dragutan, I.; Dragutan, V.; Le Gendre, P. Olefin metathesis as key step in the synthesis of bioactive compounds. Challenges in the total synthesis of iriomoteolides. Curr. Org. Synth. 2012, 9, 779-790.

272. Bicchielli, D.; Borguet, Y.; Delaude, L.; Demonceau, A.; Dragutan, I.; Dragutan, V.; Hans, M.; Jossifov, C.; Nicks, F.; Willem, Q. Olefin metathesis as key step in the synthesis of bioactive compounds. Challenges in the total synthesis of (-)-kendomycin. Curr. Org. Synth. 2012, 9, $397-405$.

273. Dragutan, I.; Dragutan, V.; Demonceau, A. Targeted drugs by olefin metathesis: Piperidine-based iminosugars. RSC Adv. 2012, 2, 719-736.

274. Dragutan, I.; Dragutan, V.; Demonceau, A.; Delaude, L. Enabling access to diverse bioactive molecules through enyne metathesis concepts. Curr. Org. Chem. 2013, 17, 2678-2720.

275. Fürstner, A. Alkyne metathesis. In Handbook of Metathesis Applications in Organic Synthesis, 2nd ed.; Grubbs, R.H., O’Leary, D.J., Eds.; Wiley-VCH: Weinheim, Germany, 2015; Volume 2, Chapter 6, pp. 445-501.

276. Grubbs, R.H.; Khosravi, E. Handbook of Metathesis. Polymer Synthesis, 2nd ed.; Wiley-VCH: Weinheim, Germany, 2015; Volume 3, p. 424.

277. Tzur, E.; Lemcoff, G. Latent ruthenium catalysts for ring opening metathesis polymerization (ROMP). In Handbook of Metathesis. Polymer Synthesis, 2nd ed.; Grubbs, R.H., Khosravi, E., Eds.; Wiley-VCH: Weinheim, Germany, 2015; Volume 3, Chapter 12, pp. 283-312.

278. Leitgeb, A.; Wappel, J.; Urbina-Blanco, C.A.; Strasser, S.; Wappl, C.; Cazin, C.S.J.; Slugovc, C. Two commercially available initiators for the retarded ring opening metathesis polymerization of dicyclopentadiene. Monatsh. Chem. 2014, 145, 1513-1517.

279. Li, M.; Song, H.; Wang, B. Synthesis and structures of $N$-heterocyclic carbene-sulfonate ruthenium complexes and their applications in the ring-opening metathesis polymerization of norbornene. Eur. J. Inorg. Chem. 2015, 2015, 4055-4061.

280. Slugovc, C. Synthesis of homopolymers and copolymers. In Handbook of Metathesis. Polymer Synthesis, 2nd ed.; Grubbs, R.H., Khosravi, E., Eds.; Wiley-VCH: Weinheim, Germany, 2015; Volume 3, Chapter 1, pp. 1-23.

281. Héroguez, V.; Chemtob, A.; Quemener, D. ROMP in dispersed media. In Handbook of Metathesis. Polymer Synthesis, 2nd ed.; Grubbs, R.H., Khosravi, E., Eds.; Wiley-VCH: Weinheim, Germany, 2015; Volume 3, Chapter 2, pp. 25-44.

282. Eissa, A.M.; Khosravi, E. Comb-like graft copolymers of poly(oxa)norbornene: Efficient synthesis using a combination of ROMP and click chemistry. Macromol. Chem. Phys. 2015, 216, 964-976.

283. Spurcaciu, B.; Buzdugan, E.; Nicolae, C.; Ghioca, P.; Iancu, L.; Dragutan, V.; Dragutan, I. New applications of ring-opening metathesis polymerization for grafting alkylene oxide-based copolymers. In Green Metathesis Chemistry: Great Challenges in Synthesis, Catalysis and Nanotechnology; Dragutan, V., Demonceau, A., Dragutan, I., Finkelshtein, E.S.; Eds.; Springer: Dordrecht, The Netherlands, 2010; pp. 409-416.

284. Kurzhals, S.; Binder, W.H. Combination of olefin metathesis polymerization with click chemistry. In Handbook of Metathesis. Polymer Synthesis, 2nd ed.; Grubbs, R.H., Khosravi, E., Eds.; Wiley-VCH: Weinheim, Germany, 2015; Volume 3, Chapter 9, pp. 207-227. 
285. Mauldin, T.C.; Boday, D.J. Self-healing polymers. In Handbook of Metathesis. Polymer Synthesis, 2nd ed.; Grubbs, R.H., Khosravi, E., Eds.; Wiley-VCH: Weinheim, Germany, 2015; Volume 3, Chapter 10, pp. 229-252.

286. Hanik, N.; Kilbinger, A.F.M. Telechelic polymers. In Handbook of Metathesis. Polymer Synthesis, 2nd ed.; Grubbs, R.H., Khosravi, E., Eds.; Wiley-VCH: Weinheim, Germany, 2015; Volume 3, Chapter 3, pp. 45-70.

287. Elacqua, E.; ten Brummelhuis, N.; Weck, M. Supramolecular polymers. In Handbook of Metathesis. Polymer Synthesis, 2nd ed.; Grubbs, R.H., Khosravi, E., Eds.; Wiley-VCH: Weinheim, Germany, 2015; Volume 3, Chapter 4, pp. 71-92.

288. Schulz, M.D.; Wagener, K.B. ADMET polymerization. In Handbook of Metathesis. Polymer Synthesis, 2nd ed.; Grubbs, R.H., Khosravi, E., Eds.; Wiley-VCH: Weinheim, Germany, 2015; Volume 3, Chapter 13, pp. 313-355.

289. Bachler, P.R.; Wagener, K.B. Functional precision polymers via ADMET polymerization. Monatsh. Chem. 2015, 146, 1053-1061.

290. Masuda, T.; Zhang, A. Polymerization of substituted acetylenes. In Handbook of Metathesis. Polymer Synthesis, 2nd ed.; Grubbs, R.H., Khosravi, E., Eds.; Wiley-VCH: Weinheim, Germany, 2015; Volume 3, Chapter 15, pp. 375-390.

291. Kiessling, L.L.; Fishman, J.M. Biologically active polymers. In Handbook of Metathesis. Polymer Synthesis, 2nd ed.; Grubbs, R.H., Khosravi, E., Eds.; Wiley-VCH: Weinheim, Germany, 2015; Volume 3, Chapter 8, pp. 169-205.

292. Phillips, J.H. Biorenewable polymers. In Handbook of Metathesis. Polymer Synthesis, 2nd ed.; Grubbs, R.H., Khosravi, E., Eds.; Wiley-VCH: Weinheim, Germany, 2015; Volume 3, Chapter 14, pp. 357-374.

293. Czelusniak, I.; Khosravi, E. Synthesis of biodegradable copolymers. In Handbook of Metathesis. Polymer Synthesis, 2nd ed.; Grubbs, R.H., Khosravi, E., Eds.; Wiley-VCH: Weinheim, Germany, 2015; Volume 3, Chapter 7, pp. 149-167.

294. Rush, A.M.; James, C.R.; Gianneschi, N.C. Synthesis of nanoparticles. In Handbook of Metathesis. Polymer Synthesis, 2nd ed.; Grubbs, R.H., Khosravi, E., Eds.; Wiley-VCH: Weinheim, Germany, 2015; Volume 3, Chapter 6, pp. 115-148.

295. Miyake, G.M.; Weitekamp, R.A.; Grubbs, R.H. Synthesis of materials with nanostructured periodicity. In Handbook of Metathesis. Polymer Synthesis, 2nd ed.; Grubbs, R.H., Khosravi, E., Eds.; Wiley-VCH: Weinheim, Germany, 2015; Volume 3, Chapter 5, pp. 93-113.

296. Bang, A.; Mohite, D.; Saeed, A.M.; Leventis, N.; Sotiriou-Leventis, C. Polydicyclopentadiene aerogels from first- versus second generation Grubbs' catalysts: A molecular versus a nanoscopic perspective. J. Sol-Gel Sci. Technol. 2015, 75, 460-474.

297. Barolo, C.; Yum, J.-H.; Artuso, E.; Barbero, N.; di Censo, D.; Lobello, M.G.; Fantacci, S.; de Angelis, F.; Grätzel, M.; Nazeeruddin, M.K.; et al. A simple synthetic route to obtain pure trans-ruthenium(II) complexes for dye-sensitized solar cell applications. ChemSusChem 2013, 6, 2170-2180.

298. Bignozzi, C.A.; Argazzi, R.; Boaretto, R.; Busatto, E.; Carli, S.; Ronconi, F.; Caramori, S. The role of transition metal complexes in dye sensitized solar devices. Coord. Chem. Rev. 2013, 257, 1472-1492. 
299. Swierk, J.R.; McCool, N.S.; Saunders, T.P.; Barber, G.D.; Mallouk, T.E. Effects of electron trapping and protonation on the efficiency of water-splitting dye-sensitized solar cells. J. Am. Chem. Soc. 2014, 136, 10974-10982.

300. Gonell, S.: Poyatos, M.; Peris, E. Pyrene-based bisazolium salts: From luminescence properties to Janus-type bis- $N$-heterocyclic carbenes. Chem. Eur. J. 2014, 20, 9716-9724.

301. Visbal, R.; Gimeno, M.C. N-heterocyclic carbene metal complexes: Photoluminescence and applications. Chem. Soc. Rev. 2014, 43, 3551-3574.

302. Dreyse, P.; Loeb, B.; Soto-Arriaza, M.; Tordera, D.; Orti, E.; Serrano-Pérez, J.J.; Bolink, H.J. Effect of free rotation in polypyridinic ligands of $\mathrm{Ru}(\mathrm{II})$ complexes applied in light-emitting electrochemical cells. Dalton Trans. 2013, 42, 15502-15513.

303. Beley, M.; Gros, P.C. Ruthenium polypyridine complexes bearing pyrroles and $\pi$-extended analogues. Synthesis, spectroelectronic, electrochemical, and photovoltaic properties. Organometallics 2014, 33, 4590-4606.

304. Sawaki, T.; Ishizuka, T.; Kawano, M.; Shiota, Y.; Yoshizawa, K.; Kojima, T. Complete photochromic structural changes in ruthenium(II)-diimine complexes, based on control of the excited states by metalation. Chem. Eur. J. 2013, 19, 8978-8990.

305. Norel, L.; di Piazza, E.; Feng, M.; Vacher, A.; He, X.; Roisnel, T.; Maury, O.; Rigaut, S. Lanthanide sensitization with ruthenium carbon-rich complexes and redox commutation of near-IR luminescence. Organometallics 2014, 33, 4824-4835.

306. Murugan, E.; Pakrudheen, I. Efficient amphiphilic poly(propylene imine) dendrimer encapsulated ruthenium nanoparticles for sensing and catalysis applications. Sci. Adv. Mater. 2015, 7, 891-901.

307. Antonels, N.C.; Meijboom, R. Preparation of well-defned dendrimer encapsulated ruthenium nanoparticles and their evaluation in the reduction of 4-nitrophenol according to the LangmuirHinshelwood approach. Langmuir 2013, 29, 13433-13442.

308. Maximov, A.; Zolotukhina, A.; Murzin, V.; Karakhanov, E.; Rosenberg, E. Ruthenium nanoparticles stabilized in cross-linked dendrimer matrices: Hydrogenation of phenols in aqueous media. ChemCatChem 2015, 7, 1197-1210.

309. Astruc, D. The olefin metathesis reactions in dendrimers. In Green Metathesis Chemistry: Great Challenges in Synthesis, Catalysis and Nanotechnology; Dragutan, V., Demonceau, A., Dragutan, I., Finkelshtein, E.S., Eds.; Springer: Dordrecht, The Netherlands, 2010; pp. 173-184.

310. Dragutan, V.; Dragutan, I.; Fischer, H. Synthesis of metal-containing polymers via ring opening metathesis polymerization (ROMP). Part II. Polymers containing transition metals. J. Inorg. Organomet. Polym. Mater. 2008, 18, 311-324.

311. Dragutan, V.; Dragutan, I.; Fischer, H. Synthesis of metal-containing polymers via ring opening metathesis polymerization (ROMP). Part I. Polymers containing main group metals. J. Inorg. Organomet. Polym. Mater. 2008, 18, 18-31.

312. Gu, H.; Rapakousiou, A.; Castel, P.; Guidolin, N.; Pinaud, N.; Ruiz, J.; Astruc, D. Living ring-opening metathesis-polymerization synthesis and redox-sensing properties of norbornene polymers and copolymers containing ferrocenyl and tetraethylene glycol groups. Organometallics 2014, 33, 4323-4335. 
313. Wang, Y.; Rapakousiou, A.; Astruc, D. ROMP synthesis of cobalticenium-enamine polyelectrolytes. Macromolecules 2014, 47, 3767-3774.

314. Rapakousiou, A.; Deraedt, C.; Gu, G.; Salmon, L.; Belin, C.; Ruiz, J.; Astruc, D. Mixed-valent click intertwined polymer units containing biferrocenium chloride side chains form nanosnakes that encapsulate gold nanoparticles. J. Am. Chem. Soc. 2014, 136, 13995-13998.

315. Rapakousiou, A.; Deraedt, C.; Irigoyen, J.; Wang, Y.; Pinaud, N.; Salmon, L.; Ruiz, J.; Moya, S.; Astruc, D. Synthesis and redox activity of "clicked" triazolylbiferrocenyl polymers, network encapsulation of gold and silver nanoparticles and anion sensing. Inorg. Chem. 2015, 54, 2284-2299.

316. Wenjuan, Y.; LeGoff, A.; Spinelli, N.; Holzinger, M.; Diao, G.-W.; Shan, D.; Defrancq, E.; Cosnier, S. Electrogenerated trisbipyridyl Ru(II)-nitrilotriacetic-polypyrene copolymer for the easy fabrication of label-free photoelectrochemical immunosensor and aptasensor: Application to the determination of thrombin and anti-cholera toxin antibody. Biosens. Bioelectron. 2013, 42, $556-562$.

317. Slugovc, C. Industrial applications of olefin metathesis polymerization. In Olefin Metathesis: Theory and Practice; Grela, K., Ed.; John Wiley \& Sons: Hoboken, NJ, USA, 2014; Chapter 10, pp. 329-333.

318. Stoianova, D.; Johns, A.; Pederson, R. Olefin metathesis: Commercial applications and future opportunities. In Handbook of Metathesis. Applications in Organic Synthesis, 2nd ed.; Grubbs, R.H., O’Leary, D.J., Eds.; Wiley-VCH: Weinheim, Germany, 2015; Volume 2, Chapter 12, pp. 699-726.

319. Seidensticker, T.; Vorholt, A.J.; Behr, A. The mission of addition and fission-Catalytic functionalization of oleochemicals. Eur. J. Lipid Sci. Technol. 2015, doi:10.1002/ejlt.201500190.

320. Elevance teams up with Malaysia's Genting to build third biorefinery. Focus Surfactants 2014, 2014, 2. Available online: http://www.sciencedirect.com/science/article/pii/S135142101470191X (accessed on 6 August 2015).

321. Butilkov, D.; Lemcoff, N.G. Jojoba oil olefin metathesis: A valuable source for bio-renewable materials. Green Chem. 2014, 16, 4728-4733.

322. Kajetanowicz, A.; Sytniczuk, A.; Grela, K. Metathesis of renewable raw materials-Influence of ligands in the indenylidene type catalysts on self-metathesis of methyl oleate and cross-metathesis of methyl oleate with (Z)-2-butene-1,4-diol diacetate. Green Chem. 2014, 16, 1579-1585.

323. Mudiyanselage, A.Y.; Viamajala, S.; Varanasi, S.; Yamamoto, K. Simple ring-closing metathesis approach for synthesis of PA11, 12, and 13 precursors from oleic acid. ACS Sustain. Chem. Eng. 2014, 2, 2831-2836.

324. Koh, M.J.; Khan, R.K.M.; Torker, S.; Yu, M.; Mikus, M.S.; Hoveyda, A.H. High-value alcohols and higher-oxidation-state compounds by catalytic Z-selective cross-metathesis. Nature 2015, 517, 181-186.

325. Tanaka Noble Metal Industrial Co, Ltd. Saccharification of Biomass Materials. Jpn. Appl. 2012-110,873, 2012.

326. Bidange, J.; Fischmeister, C.; Bruneau, C.; Dubois, J.-L.; Couturier. J.-L. Cross metathesis of bio-sourced fatty nitriles with acrylonitrile. Monatsh. Chem. 2015, 146, 1107-1113. 
327. News. Marine Pollution Bulletin 2015, 92, 4-7. doi:10.1016/j.marpolbul.2015.02.017. Available online: http://www.sciencedirect.com/science/article/pii/S0025326X1500096X (accessed on 6 August 2015).

328. Reinforced plastics. Available online: http://www.reinforcedplastics.com (accessed on 9 June 2015).

329. Skowerski, K.; Gułajski, Ł. Purification strategies in olefin metathesis. In Olefin Metathesis: Theory and Practice; Grela, K., Ed.; John Wiley \& Sons: Hoboken, NJ, USA, 2014; Chapter 25, pp. 559-571.

(C) 2015 by the authors; licensee MDPI, Basel, Switzerland. This article is an open access article distributed under the terms and conditions of the Creative Commons Attribution license (http://creativecommons.org/licenses/by/4.0/). 